Article

\title{
Influence of Site Conditions and Quality of Birch Wood on Its Properties and Utilization after Heat Treatment. Part II-Surface Properties and Marketing Evaluation of the Effect of the Treatment on Final Usage of Such Wood
}

\author{
Roman Dudík ${ }^{1}\left(0\right.$, Vlastimil Borůvka $^{2, *} \mathbb{0}$, Aleš Zeidler ${ }^{2}\left(\mathbb{D}\right.$, Tomáš Holeček $^{2}$ and Marcel Riedl $^{1}$ \\ 1 Department of Forestry and Wood Economics, Faculty of Forestry and Wood Sciences, \\ Czech University of Life Sciences Prague, 16500 Prague, Czech Republic; ro.dudik@gmail.com (R.D.); \\ riedl@fld.czu.cz (M.R.) \\ 2 Department of Wood Processing and Biomaterials, Faculty of Forestry and Wood Sciences, \\ Czech University of Life Sciences Prague, 16500 Prague, Czech Republic; zeidler@fld.czu.cz (A.Z.); \\ holecekt@fld.czu.cz (T.H.) \\ * Correspondence: boruvkav@fld.czu.cz; Tel.: +420-224-383-636
}

Received: 22 April 2020; Accepted: 11 May 2020; Published: 14 May 2020

\begin{abstract}
This work is a follow-up contribution to the characteristics of Betula pendula (silver birch) wood from different habitats and the impact of the subsequent heat treatment. Specifically, it focuses on the surface properties of birch wood in the form of veneers, namely color, hardness, roughness and wetting, and in particular on the marketing evaluation of the attractiveness of colored birch wood and, thus, its possible use in practice in the Czech Republic. Three heat treatment steps at 170, 190 and $200{ }^{\circ} \mathrm{C}$ were used. The resulting values of the properties of the treated birch veneers were compared with the untreated reference veneers and also with beech veneers. These properties were the wood density, the colorimetric parameters, the roughness parameters, the wetting parameters, the hardness and density, and none of the parameters studied showed negative changes due to the temperature adjustment. Overall, both in terms of properties and in terms of marketing appraisal, there is the potential for birch to replace, for example, beech, especially in the furniture industry, by application in the form of heat-treated veneers after suitable heat treatment. The conclusions of the marketing analysis resulting from the questionnaire survey conducted on a sample of respondents show the significant preference for the heat-treated birch wood compared to reference birch samples without heat treatment.
\end{abstract}

Keywords: heat treatment; site conditions; birch; veneer; thermowood; surface properties; attractiveness; marketing analysis; questionnaire survey; consumer preferences

\section{Introduction}

In recent years, Czech forestry has been solving the problem of declining spruce stands in lower and middle altitudes, especially in the areas of northern Moravia and the Bohemian-Moravian Highlands. The result is an increased volume of salvage fellings and the rapid emergence of areas affected by calamities, which are seeded by pioneer trees, very often birch. These clearings are then not only more difficult and more expensive to afforest with the target species, but consequently the care of the cultures to their viable stage is also problematic. While in Czech conditions, the traditional care for such cultures often involves multiple cuts of weed species, including birch. 
This article represents the second part of the investigation into birch wood properties, which also includes a marketing analysis. The main objective of this analysis is to determine whether there is any potential interest from customers for heat-treated birch wood. This potential interest can then create a prerequisite for the greater use of such wood, for example, by furniture manufacturers. The previous article, in the form of Part I [1], gives background information on the position of the birch in the forestry industry and especially in the wood processing industry of the Czech Republic. In addition, it deals specifically with the influence of the site conditions and quality of the birch wood on its properties.

It is, therefore, possible to take advantage of such cases and to regulate the self-seeded birch until its felling maturity. In the case of birch costs, lower average costs can be expected than in the Czech Republic main tree species (spruce, beech, oak, pine). When talking about the yield, it is necessary to take into account the shorter rotation period of the birch, resulting in earlier yields. In addition to the use of birch wood for energy purposes, where wood monetization can be expected for forest owners, it is possible to use high-quality round birch assortments, for example, for furniture purposes [2].

A change in the view of birch from a weed tree species to alternative production tree species is possible in the Czech Republic. However, it is necessary to provide clear information on the possibilities of processing birch wood into products with higher added value. It can be expected that the potential future demand of wood-processing companies for quality birch wood will motivate forest owners to planned birch stands tending as a prerequisite for achieving quality assortments of raw wood. Borůvka et al. [1] described more on the position of the birch in the woodworking industry in the Czech Republic.

The aim of this work is to evaluate the potential of heat-treated birch veneer for the intended use, for example, as a surface furniture veneer. This potential has two levels. On the one hand, it is necessary to consider the physical and mechanical properties of the veneer, which are important for its processing and use. On the other hand, the commercial potential of the product using heat-treated veneer is important, and the successful sale of such a product is also an economic confirmation of the right decision to use such veneers. In light of the above, changes in the parameters of the color, wettability, roughness and hardness were evaluated on samples of heat-treated veneers with a thickness of $0.9 \mathrm{~mm}$ glued to a particle board. At the same time, the potential attractiveness of the color of the selected veneer samples was identified and evaluated from the customers' perspective. The article also evaluates, from the marketing point of view, to what extent the color changes of heat-treated veneers are interesting for the customer. It is, therefore, not an economic evaluation of the production and processing of heat-treated veneers in this article, but an initial determination of whether it makes sense to consider the importance of birch wood color changes from the customer's perspective. It is a logical procedure that corresponds to the concept testing phase in the development of a new product and it is the starting point for a marketing and business analysis. This is one of the prerequisites for the successful commercialization related to the marketing. Most of the decisions to launch new products are preceded by marketing research, as reported by Bhuiyan [3]. The customers' opinions were surveyed. Given that the aim of the survey was to determine the level of attractiveness of the color samples of veneers among potentially addressed customers with regard to their preferences, the survey also included heat-treated samples of solid birch wood-see Part I [1]. Although the sample of the respondents was not large, the statistical methods analyzed the possibility to relate the results of the questionnaire survey to the whole population. It should be noted, however, that testing should not be solely restricted to this stage; it must be conducted throughout a new product development process [4] as stated in Cooper [5] building in the "voice-of-customer".

Of course, there is quite a lot of literature on general heat-treated wood or veneer [6-32], with a particular focus on birch wood or veneer [1,33-42] and specific properties, possibly with an explanation on a chemical level. Often, especially in veneers, however, it is moreover not only a heat treatment, but also a mechanical (compression) treatment under various conditions, sometimes relevant to a particular product, e.g., plywood or VTC (viscoelastic thermal compression) wood [43-46]. In any 
case, it is necessary to realize the primary intent of this contribution and its targeting on the specific use of heat-treated birch veneers and especially the opinion of potential customers.

Several works have pointed out that the heat treatment of wood provides, among other properties, an attractive color [47], while color is important from an aesthetic point of view [48,49]. Another author [50] suggests that a darker color could also be preferred by the market. In addition, the wood color is an important parameter for identifying, utilizing and determining its market value with regard to aesthetic factors [51]. Similarly, Candelier et al. [52] expresses that color is, for the final consumer, a very important feature of wood and, in some cases, is a key factor in the choice of the specific wood, as the aesthetic aspect prevails in some end users. Thus, the dark color can be an important benefit of the heat treatment that gives the wood a more valuable aspect in some countries. As a result, the modification of wood by heat treatment increases the acceptance of such wood on the European market [53]. In the context of the marketing perception of the context of the wood treatment, it is also necessary to take conclusions that point to environmental issues related to the wood treatment with preservatives into account [26]. According to the author, "new" technologies, including, among others, heat treatment of wood demonstrate the potential of these technologies. The use of new technologies is closely related to innovations in the woodworking industry. Innovations are the basic premise of commercial success in the market [54], and, in macroeconomic terms, consumption is a key driver of the economy [55]. Promotion of consumption of wood products is also one of the assumptions for increasing value added at wood-processing companies [56]. In relation to the topic of this article, the consumption is closely related to the preferences of the customers' decision-making factors influencing the purchase of furniture [57]. The most relevant purchasing decision factors are the quality, price and design of the furniture [58]. Moreover, the design is also related to the customers' perception of the furniture colors.

\section{Materials and Methods}

The sample birch tree trunks, which we used in our analysis, were taken from the forest stands of the School Forest Enterprise of the Czech University of Life Sciences in Kostelec nad Černými Lesy. The veneers from the selected section of tree No. 3 from locality No. 2 [1] were prepared as follows: Previous debarking and cooking was followed by peeling at Wotan Forest, a.s. (joint-stock company) using PCLT $800 \times 2750$ peeling machine (Raute, Nastola, Finland) and drying in a ROLLER DRYER 11R 6,20/IV oven (OMECO, Curitiba, Brazil) to an output moisture content of about $7 \%$. The choice of peeling, compared to veneer slicing, was purely economical (minimizing costs, a higher yield with a relatively lower quality). Subsequently, $0.9 \mathrm{~mm}$ thick veneers were cut into sheets of approximately $29 \times 40 \mathrm{~cm}$ and thermally treated according to the diagrams in Figure 1 in the laboratory high temperature chamber A type KHT (Katres Ltd., Jihlava, Czech Republic). For each temperature the series with at least 30 samples was used. This was followed by gluing PVAc with an Ag-cool 8761 D3 adhesive (EOC Group, Oudenaarde, Belgium) to a chipboard of $10 \mathrm{~mm}$ thickness in an amount of about $150 \mathrm{~g} / \mathrm{m}^{2}$, with a pressing pressure of $0.5 \mathrm{MPa}$ being applied for $15 \mathrm{~min}$ on a SERGIANI GS 6/90 (SCM, Rimini, Italy) veneering machine. Before the tests, all the samples were conditioned to an equilibrium moisture content in a ClimeEvent C/2000/40/3 climatic chamber (Weiss Umwelttechnik $\mathrm{GmbH}$, Reiskirchen, Germany) with a relative air humidity of $65 \% \pm 5 \%$ and a temperature of $20 \pm 2{ }^{\circ} \mathrm{C}$.

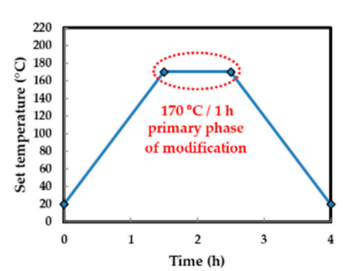

(a)

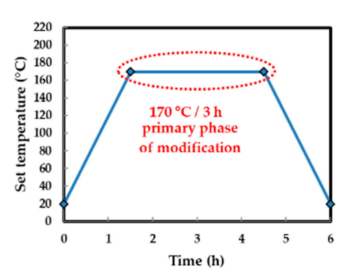

(b)

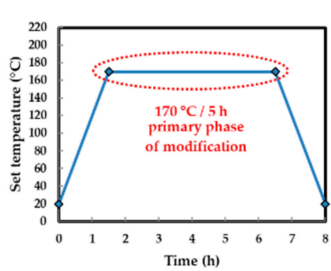

(c)

Figure 1. Cont. 


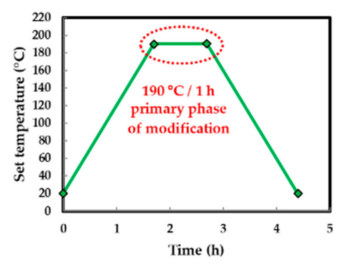

(d)

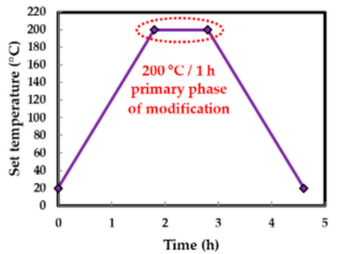

(g)

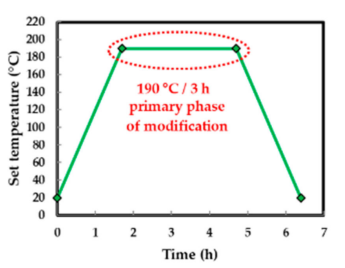

(e)

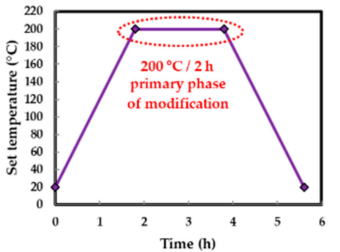

(h)

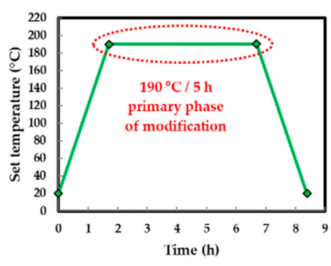

(f)

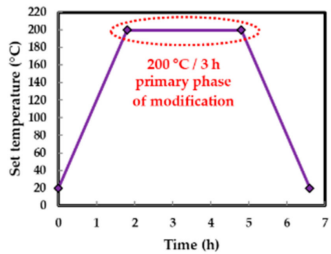

(i)

Figure 1. Diagram of the heat-treatment procedure at $170{ }^{\circ} \mathrm{C} / 1 \mathrm{~h}(\mathbf{a}), 170{ }^{\circ} \mathrm{C} / 3 \mathrm{~h}(\mathbf{b}), 170{ }^{\circ} \mathrm{C} / 5 \mathrm{~h}(\mathbf{c})$, $190{ }^{\circ} \mathrm{C} / 1 \mathrm{~h} \mathrm{(d),} 190{ }^{\circ} \mathrm{C} / 3 \mathrm{~h} \mathrm{(e),} 190{ }^{\circ} \mathrm{C} / 5 \mathrm{~h}(\mathbf{f}), 200{ }^{\circ} \mathrm{C} / 1 \mathrm{~h}(\mathrm{~g}), 200{ }^{\circ} \mathrm{C} / 2 \mathrm{~h} \mathrm{(h),} 200{ }^{\circ} \mathrm{C} / 3 \mathrm{~h} \mathrm{(i)}$.

The reader will notice that the appearance of the veneers for the experimental purposes (see Figure 2) differs from those designed for the marketing analysis (see Figure 3). The marketing analysis veneers were also first glued onto a $10 \mathrm{~mm}$ thick particleboard base, but then additionally sanded with 240 grain $/ \mathrm{cm}^{2}$ sandpaper and then treated with Ciranova-Qualität colorless wood wax (Debal Coatings, Beveren-Roeselare, Belgium) with a spreading rate of approx. $7-12 \mathrm{~m}^{2} / \mathrm{L}$ per coat. It is a traditional wax made from natural materials such as African bee wax, carnauba wax and pure turpentine. This type of protective coating was chosen to stabilize the surface layer of the treated veneer so that it does not significantly change in color shade of the individual heat treatments, and consequently prevent surface oxidation while protecting the surface from grease during the marketing investigation.

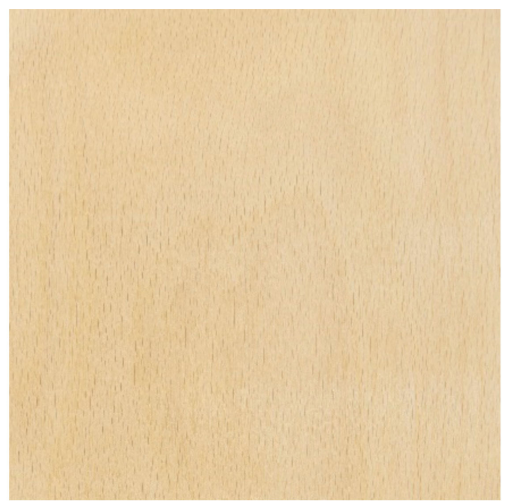

(a)

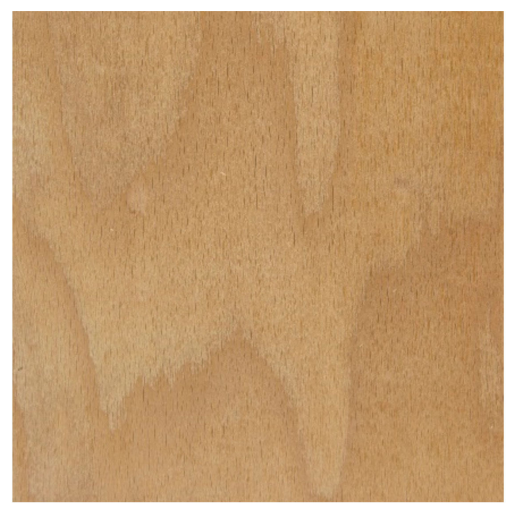

(b)

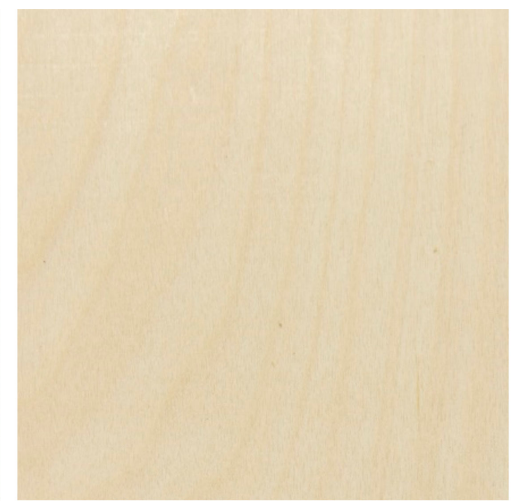

(c)

Figure 2. Cont. 


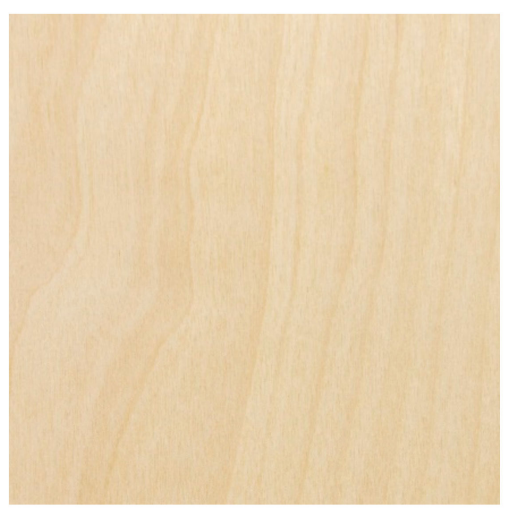

(d)

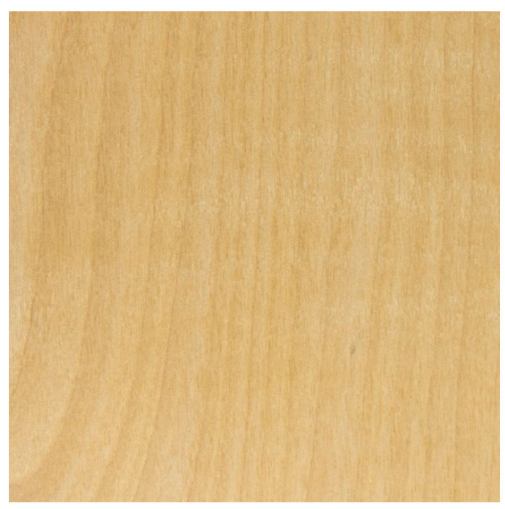

(g)

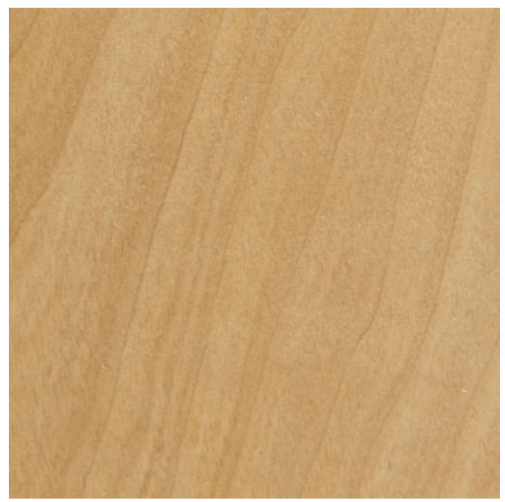

(j)

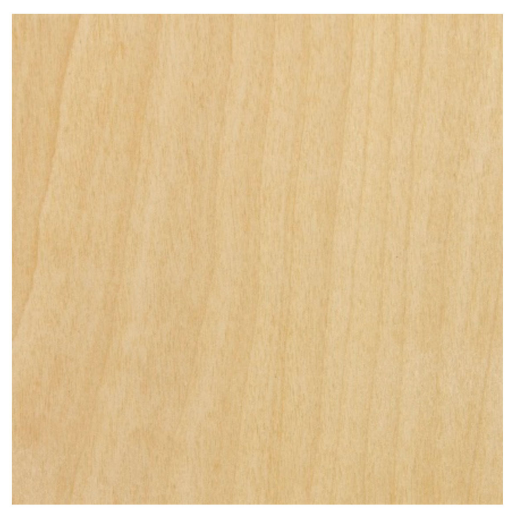

(e)

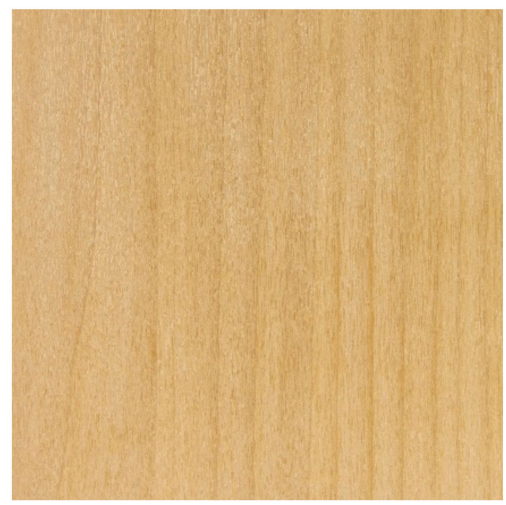

(h)

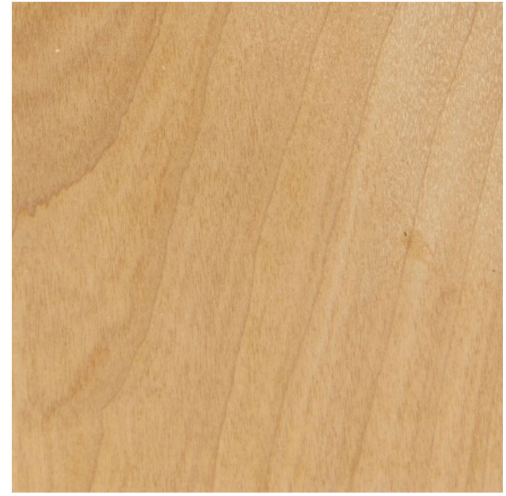

(k)

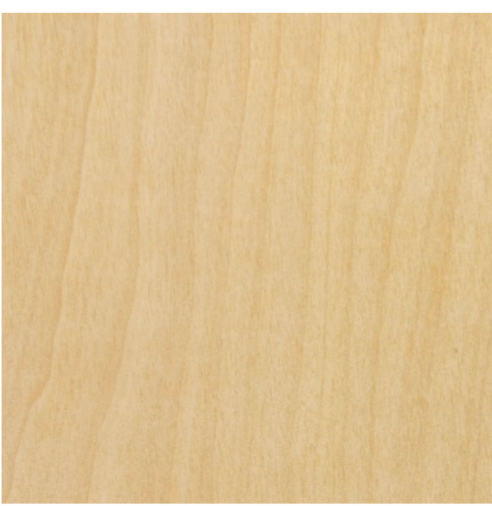

(f)

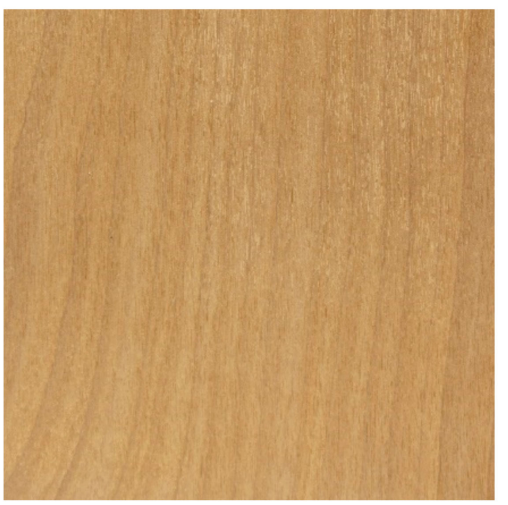

(i)

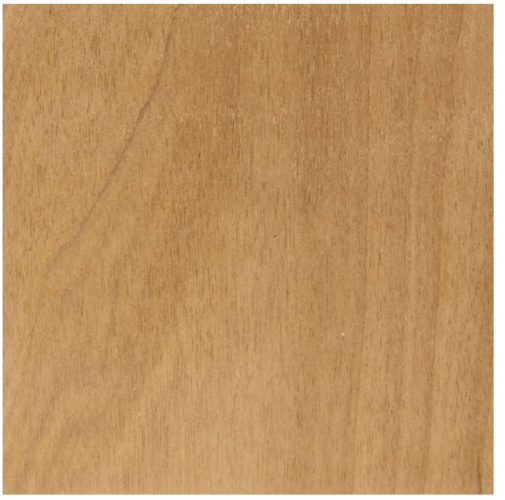

(l)

Figure 2. Photos of the reference and modified birch wood veneers intended for the experimental purposes. Untreated beech (a), beech treated at $190{ }^{\circ} \mathrm{C} / 3 \mathrm{~h}(\mathbf{b})$, untreated birch (c), birch treated at $170{ }^{\circ} \mathrm{C} / 1 \mathrm{~h}(\mathbf{d})$, birch treated at $170{ }^{\circ} \mathrm{C} / 3 \mathrm{~h}(\mathbf{e})$, birch treated at $170{ }^{\circ} \mathrm{C} / 5 \mathrm{~h}(\mathbf{f})$, birch treated at $190{ }^{\circ} \mathrm{C} / 1 \mathrm{~h}(\mathrm{~g})$, birch treated at $190{ }^{\circ} \mathrm{C} / 3 \mathrm{~h}(\mathbf{h})$, birch treated at $190{ }^{\circ} \mathrm{C} / 5 \mathrm{~h}(\mathbf{i})$, birch treated at $200{ }^{\circ} \mathrm{C} / 1 \mathrm{~h}(\mathbf{j})$, birch treated at $200{ }^{\circ} \mathrm{C} / 2 \mathrm{~h} \mathrm{(k),} \mathrm{birch} \mathrm{treated} \mathrm{at} 200{ }^{\circ} \mathrm{C} / 3 \mathrm{~h} \mathrm{(1)}$. 


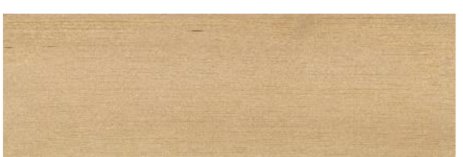

(a)

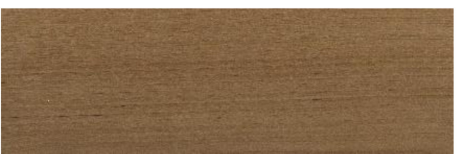

(d)

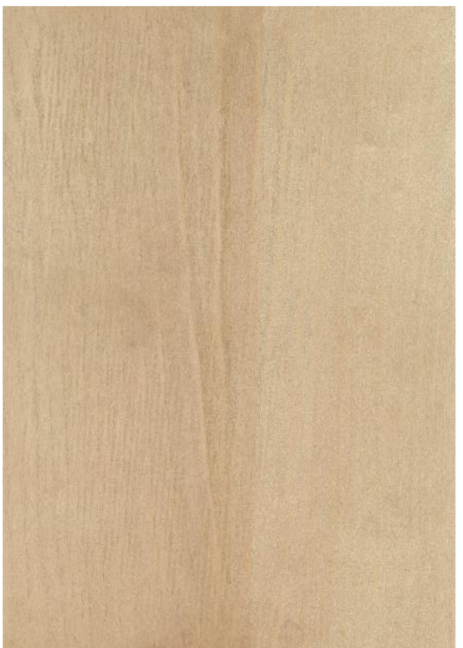

(g)

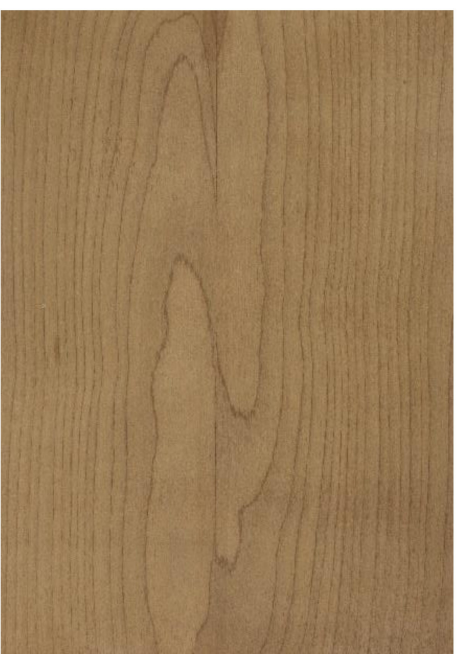

(j)

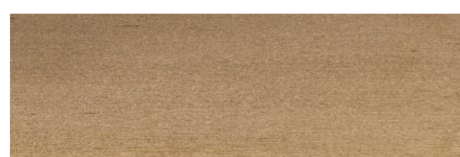

(b)

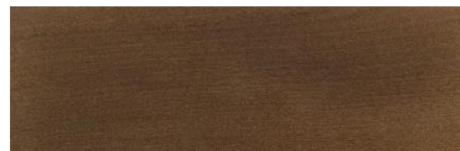

(e)

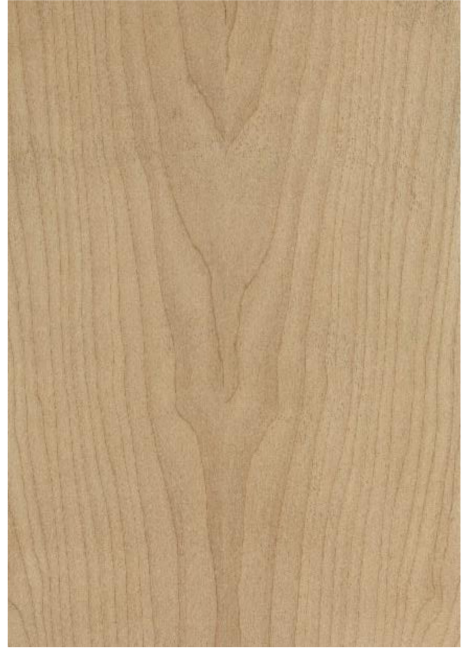

(h)

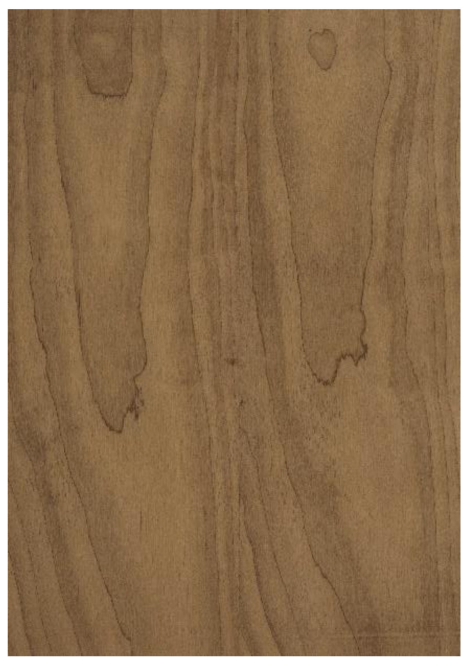

(k)

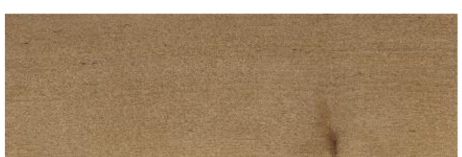

(c)

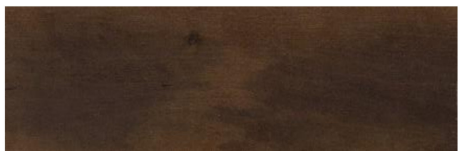

(f)

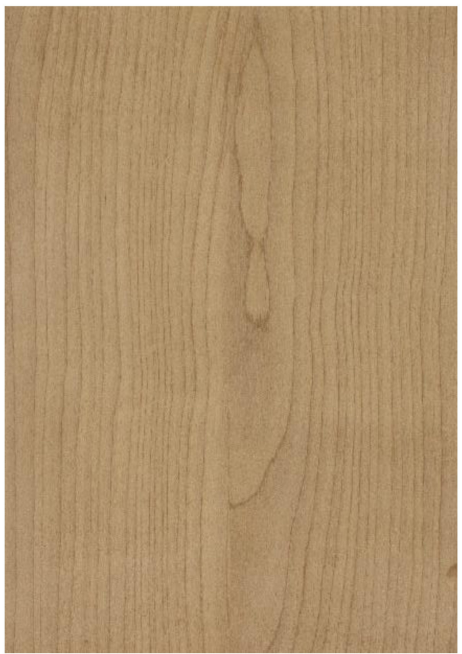

(i)

Figure 3. Photos of the peeled veneer and solid wood of the reference and modified birch wood intended for the marketing evaluation. Solid wood-untreated (a), solid wood-treated at $160{ }^{\circ} \mathrm{C} / 3 \mathrm{~h}$ (b), solid wood-treated at $170{ }^{\circ} \mathrm{C} / 3 \mathrm{~h}(\mathbf{c})$, solid wood-treated at $180^{\circ} \mathrm{C} / 3 \mathrm{~h}(\mathrm{~d})$, solid wood-treated at $190{ }^{\circ} \mathrm{C} / 3 \mathrm{~h}(\mathbf{e})$, solid wood - treated at $200{ }^{\circ} \mathrm{C} / 3 \mathrm{~h}(\mathbf{f})$, veneer-untreated $(\mathrm{g})$, veneer-treated at $170{ }^{\circ} \mathrm{C} / 3 \mathrm{~h}(\mathbf{h})$, veneer-treated at $190{ }^{\circ} \mathrm{C} / 3 \mathrm{~h}(\mathbf{i})$, veneer-treated at $190{ }^{\circ} \mathrm{C} / 5 \mathrm{~h}(\mathbf{j})$, veneer-treated at $200{ }^{\circ} \mathrm{C} / 3 \mathrm{~h}(\mathbf{k})$. 


\subsection{Experimental Tests}

The ability of liquids to wet the wood surface is judged by the extent of the contact angle. Based on its determination, we also predicted the efficiency of the thermal modification of the wood on the subsequent adhesive strength of the adhesives, although we did not determine the free surface energy of the wood. It is, of course, known that the contact angle of liquids increases after thermal treatment, and, in the case of thin veneers, there is a presumption of the influence of the glued joint on the change of the hydrophilicity or the respective hydrophobicity, which, from a certain stage, outweighs the effect of intentionally targeted thermal modification (surface) of wood. The measurements were based on the works $[8,14,15,21]$.

The wood wetting was accomplished by dropping a $1.8 \mu \mathrm{L}$ drop of water onto the wood surface. After the impact of the droplet, the surface of the wood was scanned by a camera, as the result of the penetration into the substrate which results in a permanent change in the angle with time and, in most cases, the complete absorption of the liquid into the substrate, making it practically impossible to determine equilibrium contact angle. The contact angle and drop diameter were determined for the time immediately after impact, and 1 and 2 min after the impact. In a similar way, we measured the contact angle on impact with a droplet of $5.0 \mu \mathrm{L}$ at $5 \mathrm{~s}$ after the impact of the droplet, which is the most frequent time quoted in the literature.

The color of the wood, as well as the roughness and, in a way, the hardness, is a hallmark of its surface. It is an important aesthetic feature. Since heat treatment changes the color of the wood, it is necessary to recognize these changes as well as their causes. Given the customers' preference for dark wood colors, this change can be, and is, a very positive property of the thermal treatment. The degree of the color change is determined by the total color difference $\Delta \mathrm{E}^{*}\left(\mathrm{dE}^{*}\right)$ within the color space measurement CIE $\mathrm{L}^{*} \mathrm{a}^{*} \mathrm{~b}^{*}$, and generally decreases with increasing temperature and time of the thermal treatment. Speaking of temperatures up to $200{ }^{\circ} \mathrm{C}$, the lightness $\mathrm{L}^{*}$ decreases and the parameters $a^{*}$ and $b^{*}$ increase. These changes are the result of chemical reactions, in particular, the degradation of the hemicelluloses and the formation of oxidation products, and, to a certain extent, changes in the lignin, which are not so pronounced at temperatures up to $200{ }^{\circ} \mathrm{C}$.

In terms of the purely methodological and instrumental equipment (principally, see Figure 4), the following procedure was followed: The color measurement was performed with a CM-600d Spectrophotometer (Konica Minolta, Osaka, Japan) in accordance with EN ISO 11664-4 [59] and EN ISO 11664-6 [60]. The roughness parameters were methodically determined in accordance with the ČSN EN ISO 4287 [61] and ČSN EN ISO 4288 [62] standards using a stationary Form Talysurf 50 profile measurement gauge (Taylor Hobson Ltd. Leicester, United Kingdom) and also using an Olympus LEXT OLS4100 laser scanning microscope (Olympus Europa SE \& Co. KG, Hamburg, Germany). The wettability measurement was performed on a KRÜSS DSA30 drop shape analyzer (KRÜSS GmbH, Hamburg, Germany) in accordance with the above methodology. The hardness measurement was performed in accordance with EN 1534 [63] on a DuraVision-30 hardness tester (Struers GmbH, Willich, Germany). The veneer density was determined in accordance with ČSN 490108 [64], and was determined from the relevant point of view by comparing the values of the above monitored values (excluding the roughness) achieved on the birch (all the kinds of the thermal treatment) with the values of the reference beech wood veneers.

For the statistical evaluation, basic descriptive statistics and a subsequent ANOVA (analysis of variance) were used to evaluate the significance of the heat treatment factor. The same significance level $\alpha=0.05$ was used for the analyses (95\% confidence interval in graphical visualization). All the analyses of the experimental data were performed in STATISTICA Version 13.4.0.14 (TIBCO Software Inc., Palo Alto, USA). 


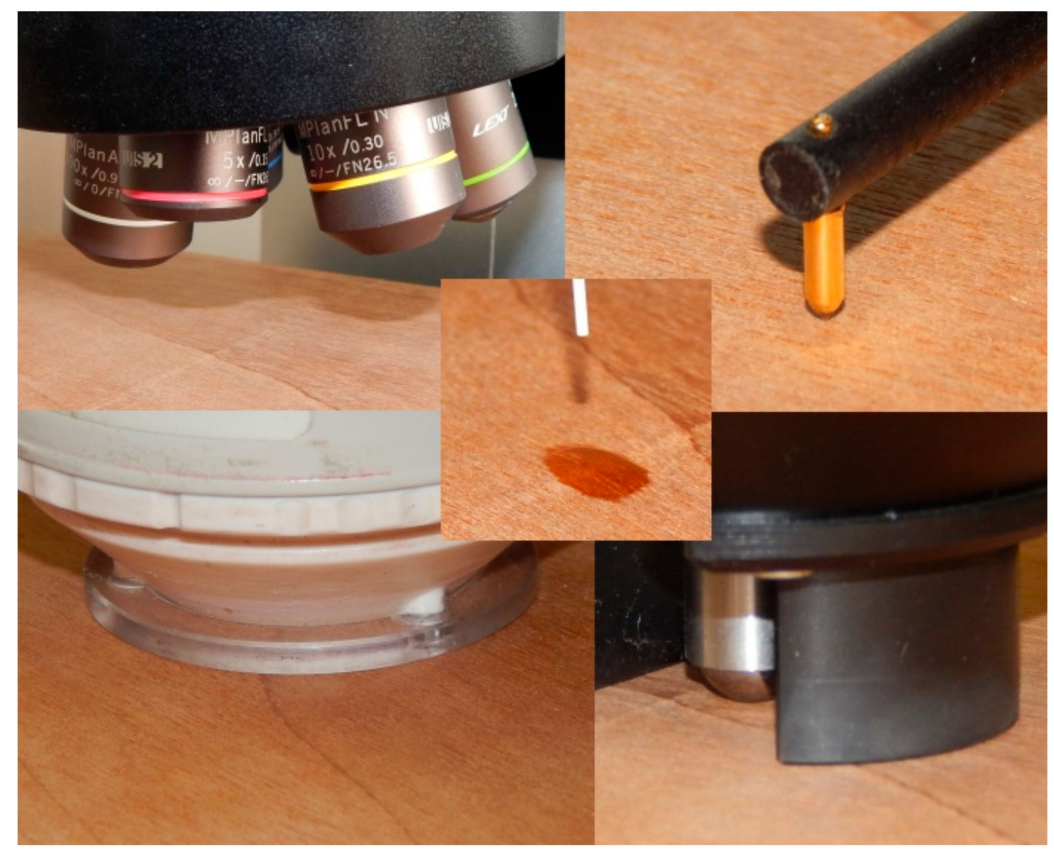

Figure 4. The photographic details of the principle of experimental measurements.

\subsection{Marketing Analysis}

The basis of the marketing analysis is a questionnaire survey on a random sample of 102 persons from the population of the Czech Republic. The color appearance of the selected real samples was determined and evaluated separately for the solid wood (one reference sample and five samples with different degrees in the thermal treatment) and separately for the veneer (one reference sample and four samples with different degrees of the thermal treatment)—see Figure 3. All the birch samples analyzed in the research published in Part I [1] were included in the selection of the solid wood samples. The veneer samples used included the selected birch veneer samples that showed a visually discernible color change in the veneer samples from a light color (reference sample) to the darkest color (birch treated at $200{ }^{\circ} \mathrm{C} / 3 \mathrm{~h}$ ). The attractiveness of the color appearance was determined in two basic variants. In the first variant, the attractiveness of the color samples was determined in principle in the case of the first furnishing of a new house/apartment with furniture (e.g., living room). In the second variant, it was the purchase of a piece of furniture (e.g., for a living room) for the existing equipment of the house/apartment. In both variants, the respondents were supposed to select one of the solid wood samples and one of the veneer samples. Another important piece of information was the level of attractiveness of each individual solid wood and veneer sample, which was evaluated according to the selected point scale (1 point-the least preferable; 5 points-the most preferable). In this case, the sensitivity of the attractiveness of the individual samples was determined. In addition, the gender, age, educational attainment and whether the respondent had a forestry or timber education, were surveyed for each respondent. The last optional question asked the respondents their opinion on the wood species from which the individual samples were made.

The formulated questions used in the questionnaire survey are given in Appendix A (see Figure A1). For the solid wood samples, the reference numerals I to VI were used, the reference sample was marked I. For the veneer samples, the letters A to E were used, the reference sample was marked A. Respondents chose preferences for individual samples based on color differences. Respondents had no information when choosing preferences about what caused the color differences of individual samples. They also did not have information on the tree species of individual samples. These facts were communicated to them during the interview after they submitted their questionnaires.

The data obtained by the questionnaire survey were processed in the first phase by graphical methods of descriptive statistics. The statistical significance of the preference differences between 
the different groups of respondents was evaluated using the Chi-square Goodness of the Fit Test. The estimation of the proportion of the people in the population preferring thermal wood treatment was made as an interval estimate of the p-binomial distribution parameter [65], i.e.,

$$
P\left[\frac{x}{n}-u(\alpha / 2) \sqrt{\frac{x / n(1-x / n)}{n}}<p<\frac{x}{n}+u(\alpha / 2) \sqrt{\frac{x / n(1-x / n)}{n}}\right]=1-\alpha
$$

The statistical evaluation of the questionnaire survey was performed in the program $\mathrm{R}$ Version 3.6.1. (The R Foundation, Austria). The same significance level $\alpha=0.05$ was used for the analyses.

\section{Results and Discussion}

\subsection{Evaluation of the Experiments}

Tables 1-4 show the basic statistical characteristics (averages and standard deviations) of all the examined variables, i.e., the color, roughness, wetting, hardness and, last but not least, density, of both the untreated and heat-treated birch veneer, and also for the relevant comparison of the untreated beech wood in some cases. Three different treatment grades $\left(170,190\right.$ and $\left.200{ }^{\circ} \mathrm{C}\right)$ were used and for each of the stages with three different durations in the peak temperature phase $(1,3$ and $5 \mathrm{~h}$ for the 170 and $190{ }^{\circ} \mathrm{C}$ temperature stages and 1,2 , and $3 \mathrm{~h}$ for the $200{ }^{\circ} \mathrm{C}$ temperature stage). Figures $5-12$ show graphical visualization of the above outputs, which is illustrative from the view of the possible trend. A statistically significant effect of the degree of the heat treatment was found for all the investigated variables, but not, of course, among all the degrees of each other (see the graphical visualization).

Table 1. The basic statistical analyses of the roughness parameters determined by the optical method.

\begin{tabular}{ccccccccccc}
\hline $\begin{array}{c}\text { Mean } \\
\text { Std.Dev. }\end{array}$ & BR-REF & BR-170-1 & BR-170-3 & BR-170-5 & BR-190-1 & BR-190-3 & BR-190-5 & BR-200-1 & BR-200-2 & BR-200-3 \\
\hline \multirow{2}{*}{$\operatorname{Ra}(\mu \mathrm{m})$} & 2.666 & 4.006 & 3.280 & 3.560 & 1.833 & 1.369 & 2.396 & 3.074 & 1.515 & 1.551 \\
& 0.967 & 1.691 & 1.491 & 1.100 & 1.272 & 0.827 & 1.763 & 2.614 & 0.326 & 1.508 \\
\hline \multirow{2}{*}{$\operatorname{Rz}(\mu \mathrm{m})$} & 33.796 & 37.492 & 49.256 & 42.647 & 19.491 & 18.662 & 19.851 & 33.100 & 15.938 & 18.748 \\
& 15.069 & 13.697 & 22.016 & 18.468 & 9.092 & 9.121 & 11.420 & 17.353 & 2.471 & 18.636 \\
\hline \multirow{2}{*}{$\mathrm{RSm}(\mu \mathrm{m})$} & 58.999 & 59.248 & 63.149 & 48.701 & 37.851 & 50.302 & 47.800 & 53.444 & 74.702 & 48.657 \\
& 13.759 & 14.869 & 19.613 & 19.799 & 25.877 & 24.192 & 20.748 & 12.569 & 15.941 & 20.567 \\
\hline \multirow{2}{*}{$\mathrm{Rc}(\mu \mathrm{m})$} & 11.075 & 12.666 & 12.276 & 10.208 & 4.829 & 5.937 & 8.737 & 8.950 & 7.641 & 6.492 \\
& 3.476 & 5.634 & 4.759 & 3.881 & 1.543 & 3.426 & 7.153 & 3.615 & 1.558 & 5.760 \\
\hline
\end{tabular}

Valid $N=30$ (for all series). BR-REF $=$ untreated birch; BR-170-1 = birch treated at $170{ }^{\circ} \mathrm{C} / 1 \mathrm{~h}$; BR-170-3 = birch treated at $170{ }^{\circ} \mathrm{C} / 3 \mathrm{~h}$; BR-170-5 = birch treated at $170{ }^{\circ} \mathrm{C} / 5 \mathrm{~h}$; BR-190- $1=$ birch treated at $190^{\circ} \mathrm{C} / 1 \mathrm{~h}$; BR-190-3 = birch treated at $190{ }^{\circ} \mathrm{C} / 3 \mathrm{~h}$; BR-190- $5=$ birch treated at $190{ }^{\circ} \mathrm{C} / 5 \mathrm{~h}$; BR-200- $1=$ birch treated at $200{ }^{\circ} \mathrm{C} / 1 \mathrm{~h}$; BR-200-2 = birch treated at $200^{\circ} \mathrm{C} / 2 \mathrm{~h}$; BR-200-3 = birch treated at $200^{\circ} \mathrm{C} / 3 \mathrm{~h}$; Std.Dev. = standard deviation; Ra = average arithmetical deviation of the profile; $\mathrm{Rz}=$ distance between the highest peak and lowest valley in the basic length range; $\mathrm{RSm}=$ average width of profile elements; $\mathrm{Rc}=$ average height of the profile.

Table 2. The basic statistical analyses of the roughness parameters determined by the contact method.

\begin{tabular}{ccccccccccc}
\hline $\begin{array}{c}\text { Mean } \\
\text { Std.Dev. }\end{array}$ & BR-REF & BR-170-1 & BR-170-3 & BR-170-5 & BR-190-1 & BR-190-3 & BR-190-5 BR-200-1 & BR-200-2 & BR-200-3 \\
\hline \multirow{2}{*}{$\operatorname{Ra}(\mu \mathrm{m})$} & 2.005 & 2.131 & 2.080 & 2.545 & 2.256 & 2.500 & 2.004 & 1.948 & 2.104 & 1.835 \\
& 0.165 & 0.204 & 0.151 & 0.164 & 0.198 & 0.138 & 0.144 & 0.246 & 0.232 & 0.199 \\
\hline \multirow{2}{*}{$\operatorname{Rc}(\mu \mathrm{m})$} & 11.671 & 11.270 & 11.377 & 12.569 & 10.495 & 12.074 & 10.351 & 9.873 & 10.844 & 9.267 \\
& 1.169 & 1.111 & 1.101 & 1.010 & 0.953 & 0.870 & 0.915 & 1.443 & 1.290 & 1.210 \\
\hline \multirow{2}{*}{$\mathrm{RSm}(\mu \mathrm{m})$} & 103.010 & 93.563 & 95.014 & 91.817 & 80.000 & 92.197 & 89.377 & 84.742 & 84.501 & 85.442 \\
& 14.624 & 8.287 & 13.392 & 15.894 & 9.834 & 8.914 & 12.505 & 14.067 & 15.089 & 11.372 \\
\hline
\end{tabular}

Valid $N=30$ (for all series). BR-REF = untreated birch; BR-170-1 = birch treated at $170{ }^{\circ} \mathrm{C} / 1 \mathrm{~h}$; BR-170-3 = birch treated at $170{ }^{\circ} \mathrm{C} / 3 \mathrm{~h}$; BR-170-5 = birch treated at $170{ }^{\circ} \mathrm{C} / 5 \mathrm{~h}$; BR-190- $1=$ birch treated at $190{ }^{\circ} \mathrm{C} / 1 \mathrm{~h}$; BR-190-3 = birch treated at $190{ }^{\circ} \mathrm{C} / 3 \mathrm{~h}$; BR-190-5 = birch treated at $190^{\circ} \mathrm{C} / 5 \mathrm{~h}$; BR-200- $1=$ birch treated at $200{ }^{\circ} \mathrm{C} / 1 \mathrm{~h}$; BR-200-2 = birch treated at $200^{\circ} \mathrm{C} / 2 \mathrm{~h}$; BR-200-3 = birch treated at $200^{\circ} \mathrm{C} / 3 \mathrm{~h}$; Std.Dev. = standard deviation; Ra = average arithmetical deviation of the profile; $\mathrm{RSm}=$ average width of profile elements; Rc = average height of the profile. 
Table 3. The basic statistical analyses of the colorimetric parameters, hardness and density.

\begin{tabular}{cccccccccccc}
\hline $\begin{array}{c}\text { Mean } \\
\text { Std.Dev. }\end{array}$ & BK-REF & BR-REF & BR-170-1 & BR-170-3 & BR-170-5 & BR-190-1 & BR-190-3 & BR-190-5 & BR-200-1 & BR-200-2 & BR-200-3 \\
\hline \multirow{2}{*}{$\mathrm{L}^{*}$} & 69.92 & 82.94 & 76.19 & 70.94 & 70.11 & 66.12 & 63.32 & 55.84 & 59.10 & 57.03 & 51.33 \\
& 3.54 & 6.12 & 1.10 & 1.30 & 1.02 & 1.17 & 1.41 & 1.64 & 4.86 & 1.65 & 1.33 \\
\hline \multirow{2}{*}{$\mathrm{a}^{*}$} & 9.14 & 3.50 & 6.60 & 8.22 & 8.53 & 9.43 & 10.75 & 11.07 & 10.86 & 10.66 & 11.71 \\
& 1.16 & 0.37 & 0.44 & 0.46 & 0.37 & 0.36 & 7.82 & 0.88 & 0.28 & 0.35 & 0.86 \\
\hline \multirow{2}{*}{$\mathrm{b}^{*}$} & 22.84 & 17.12 & 22.22 & 26.20 & 25.32 & 26.88 & 27.17 & 26.34 & 26.34 & 24.80 & 25.10 \\
& 1.05 & 0.45 & 0.62 & 18.18 & 1.01 & 0.99 & 1.61 & 0.65 & 0.55 & 0.73 & 0.71 \\
\hline \multirow{2}{*}{$\Delta \mathrm{E}^{*}$} & 74.16 & 84.81 & 79.64 & 76.80 & 75.04 & 72.01 & 70.04 & 62.74 & 65.71 & 63.11 & 58.34 \\
& 3.00 & 5.42 & 0.92 & 14.84 & 0.88 & 0.92 & 4.73 & 1.44 & 3.20 & 1.52 & 1.17 \\
\hline \multirow{2}{*}{ Hardness $(\mathrm{MPa})$} & 38 & 30 & 29 & 28 & 30 & 31 & 32 & 32 & 38 & 36 \\
& 8 & 9 & 7 & 8 & 7 & 8 & 8 & 8 & 9 & 10 \\
\hline \multirow{2}{*}{ Density ** $\left(\mathrm{kg} / \mathrm{m}^{3}\right)$} & 711 & 608 & 598 & 586 & 592 & 593 & 595 & 570 & 599 & 568 \\
& 8 & 9 & 3 & 3 & 5 & 16 & 4 & 7 & 22 & 12 \\
\hline
\end{tabular}

Valid $N=150$ for all properties within heat treatment degree $(* *$-exception: $N=30)$. BK-REF $=$ untreated beech; BR-REF = untreated birch; BR-170-1 = birch treated at $170{ }^{\circ} \mathrm{C} / 1 \mathrm{~h}$; BR-170-3 = birch treated at $170{ }^{\circ} \mathrm{C} / 3 \mathrm{~h}$; BR-170-5 = birch treated at $170{ }^{\circ} \mathrm{C} / 5 \mathrm{~h}$; BR-190-1 = birch treated at $190^{\circ} \mathrm{C} / 1 \mathrm{~h}$; BR-190-3 = birch treated at $190{ }^{\circ} \mathrm{C} / 3 \mathrm{~h} ; \mathrm{BR}-190-5=$ birch treated at $190^{\circ} \mathrm{C} / 5 \mathrm{~h}$; BR-200- $1=$ birch treated at $200^{\circ} \mathrm{C} / 1 \mathrm{~h}$; BR-200-2 = birch treated at $200{ }^{\circ} \mathrm{C} / 2 \mathrm{~h}$; BR-200-3 $=$ birch treated at $200{ }^{\circ} \mathrm{C} / 3 \mathrm{~h}$; Std.Dev. = standard deviation; $\mathrm{L}^{*}=$ brightness; $\mathrm{a}^{*}=$ value in the green-red axis; $\mathrm{b}^{*}=$ value in the blue-yellow axis; $\Delta \mathrm{E}^{*}=$ total color difference.

Table 4. The basic statistical analyses of the wetting parameters.

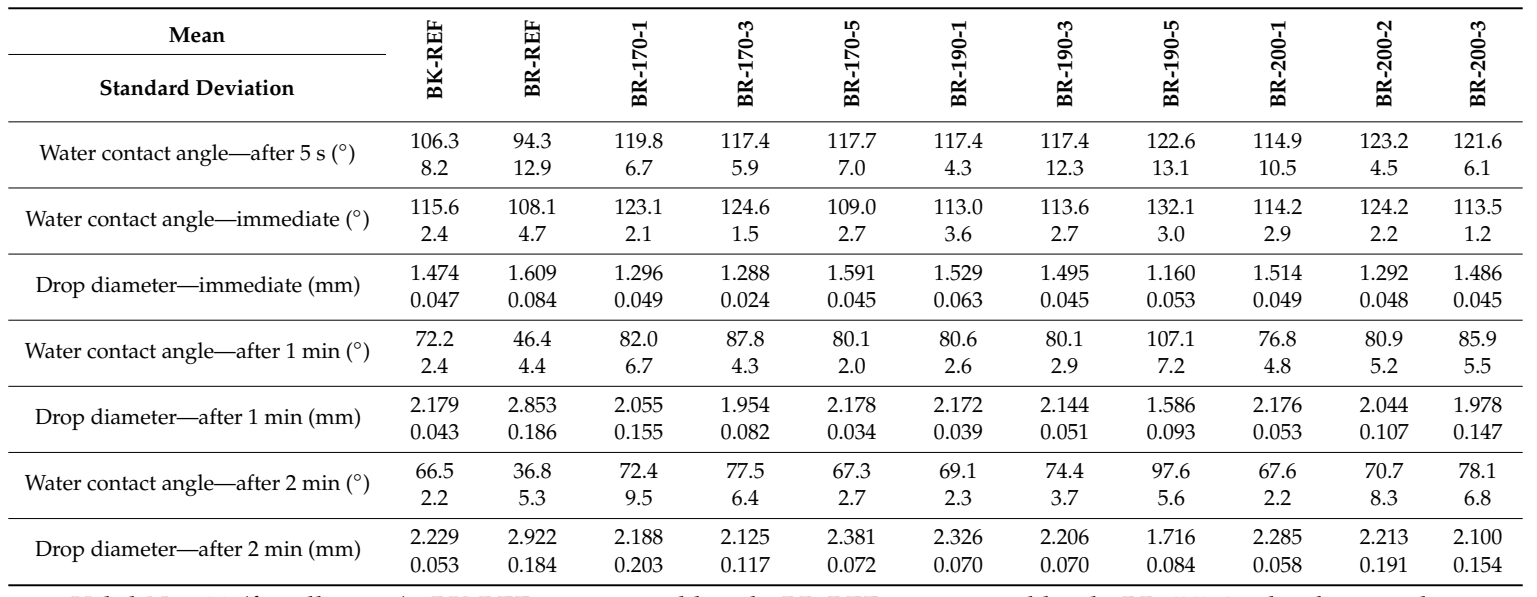

Valid $N=30$ (for all series). BK-REF = untreated beech; BR-REF $=$ untreated birch; BR-170-1 $=$ birch treated at $170{ }^{\circ} \mathrm{C} / 1 \mathrm{~h}$; BR-170-3 = birch treated at $170{ }^{\circ} \mathrm{C} / 3 \mathrm{~h}$; BR-170-5 = birch treated at $170{ }^{\circ} \mathrm{C} / 5 \mathrm{~h}$; BR-190-1 = birch treated at $190^{\circ} \mathrm{C} / 1 \mathrm{~h}$; BR-190-3 = birch treated at $190^{\circ} \mathrm{C} / 3 \mathrm{~h}$; BR-190-5 = birch treated at $190^{\circ} \mathrm{C} / 5 \mathrm{~h}$; BR-200-1 = birch treated at $200{ }^{\circ} \mathrm{C} / 1 \mathrm{~h} ; \mathrm{BR}-200-2=$ birch treated at $200^{\circ} \mathrm{C} / 2 \mathrm{~h}$; BR-200-3 = birch treated at $200{ }^{\circ} \mathrm{C} / 3 \mathrm{~h}$.

In the case of the roughness, it was only a matter of finding out whether the heat treatment had a negative effect on the roughness parameters $\mathrm{Ra}$ (average arithmetical deviation of the profile), $\mathrm{Rz}$ (distance between the highest peak and lowest valley in the basic length range), RSm (average width of profile elements) and Rc (average height of the profile), i.e., if the treatment increases these parameters. No negative trend was found between the testing series (see Figures 5 and 6 ). A statistically significant difference has been shown between some series, but this is related to the natural variability of wood and not to the effect of the heat treatment (see e.g., Figure 7).

The color parameters pointed to a logically positive trend in the decreasing luminance (the parameter $\left.L^{*}\right)$ and the overall color difference $\left(\Delta \mathrm{E}^{*}\right)$, i.e., the transition to warmer brown shades with an increase in the treatment temperature and possibly peak time temperature (see Figure 8a-d). The beech parameters were already reached at $170^{\circ} \mathrm{C} / 5 \mathrm{~h}$ and $190^{\circ} \mathrm{C} / 1 \mathrm{~h}$ respectively (see Figure 9 ). It is one of the most important factors in the decision making of potential customers (see the marketing analysis), because it is a visually perceptible phenomenon, unlike all the other investigated variables, which are more or less "technical" in nature. However, it is evident in the way that the respondents perceived the solid wood and the veneer in an otherwise different way, which is related to more complex characteristics (haptic properties), i.e., not only the color and texture (see Figure 3). 


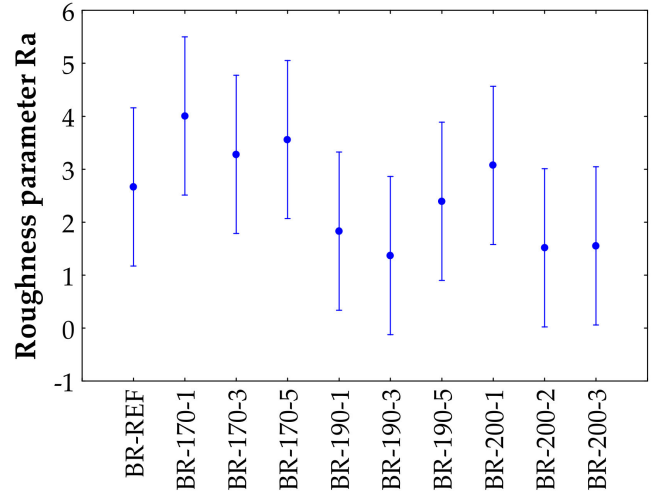

(a)

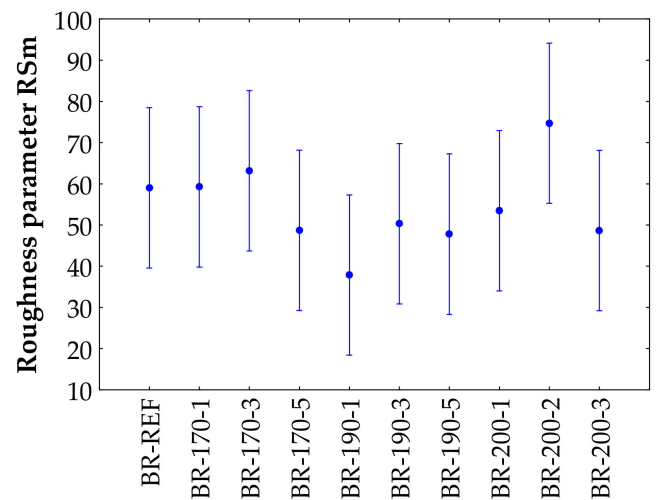

(c)

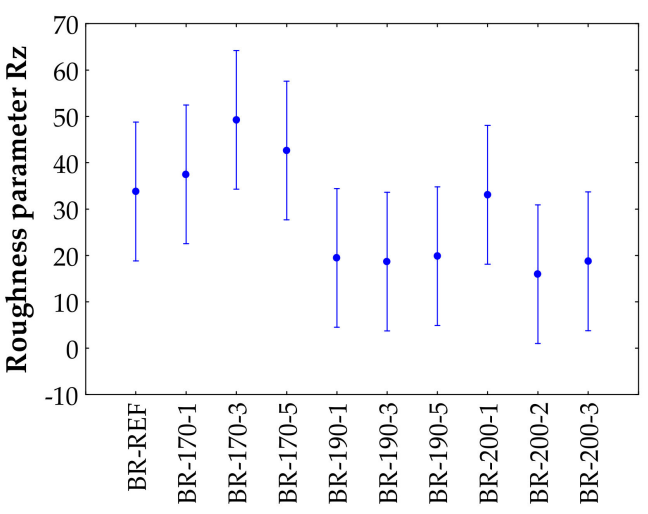

(b)

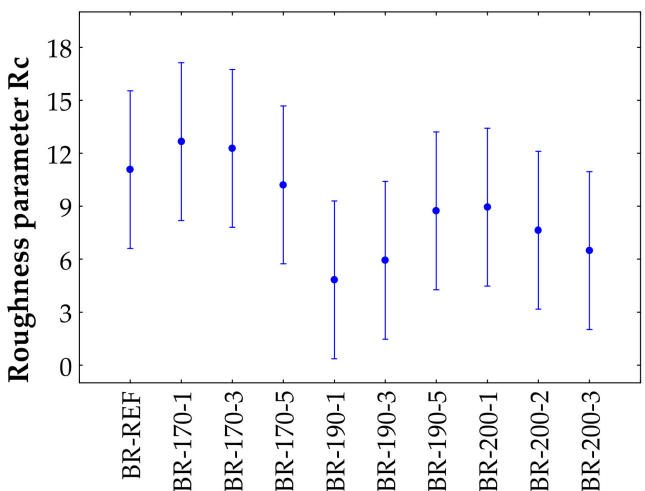

(d)

Figure 5. The graphic visualization of the effect of heat-treatment temperature and heat-treatment time limit (peak stage) on roughness parameters determined by optical method (a) Ra, (b) Rz, (c) RSm and (d) Rc. BR-REF = untreated birch; BR-170-1 = birch treated at $170{ }^{\circ} \mathrm{C} / 1 \mathrm{~h}$; BR-170-3 = birch treated at $170{ }^{\circ} \mathrm{C} / 3 \mathrm{~h}$; BR-170-5 = birch treated at $170{ }^{\circ} \mathrm{C} / 5 \mathrm{~h}$; BR-190-1 = birch treated at $190{ }^{\circ} \mathrm{C} / 1 \mathrm{~h}$; BR-190-3 = birch treated at $190{ }^{\circ} \mathrm{C} / 3 \mathrm{~h}$; BR-190-5 = birch treated at $190^{\circ} \mathrm{C} / 5 \mathrm{~h}$; BR-200-1 = birch treated at $200{ }^{\circ} \mathrm{C} / 1 \mathrm{~h}$; BR-200-2 = birch treated at $200{ }^{\circ} \mathrm{C} / 2 \mathrm{~h}$; BR-200-3 = birch treated at $200{ }^{\circ} \mathrm{C} / 3 \mathrm{~h}$. Ra = the average arithmetical deviation of the profile; $\mathrm{Rz}=$ the distance between the highest peak and the lowest valley in the basic length range; $\mathrm{RSm}=$ the average width of the profile elements; $\mathrm{Rc}=$ the average height of the profile.

The wetting parameters, both the contact angle and the drop diameter, also pointed to a positive trend in the wettability of the treated birch wood veneers (see Figure 10). Even at the lowest degree of treatment of $170{ }^{\circ} \mathrm{C} / 1 \mathrm{~h}$, the values were improved over the values measured on the samples in the untreated state, so that they were improved to a level above the untreated beech veneer (see, e.g., Figure 11). The trend was then more or less constant and mostly statistically insignificant, which is related to the fact that the $0.9 \mathrm{~mm}$ thick veneer was glued to the chipboard substrate. Therefore, the wettability was also influenced by this factor, i.e., the glue, but even so, the increasing trend in the contact angle even in the solid wood was already noticeable. This, however, certainly affected the wetting itself of the untreated veneers and the heat treatment enhanced this phenomenon. For veneers with a thickness of $0.6 \mathrm{~mm}$, this would probably be even more striking, due to closer contact of the adhesive. In any case, in the view of the adhesive strength of the adhesives, there was no significant difference between the different temperature stages of the treated veneers. 


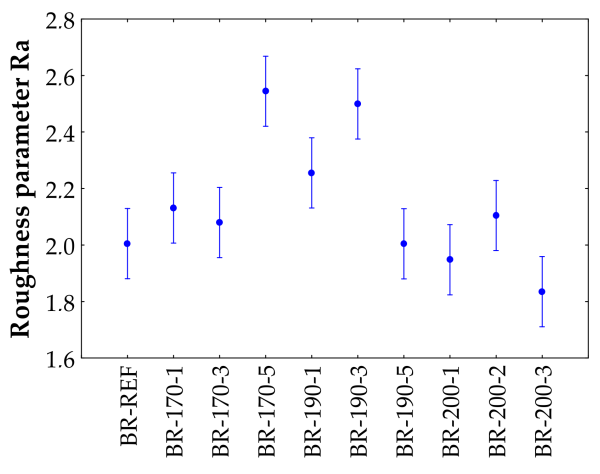

(a)

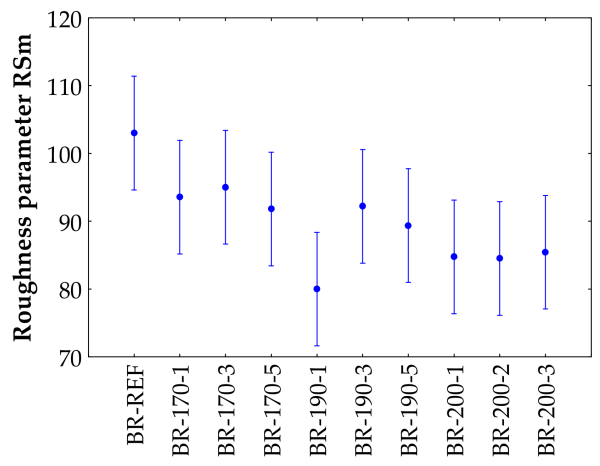

(c)

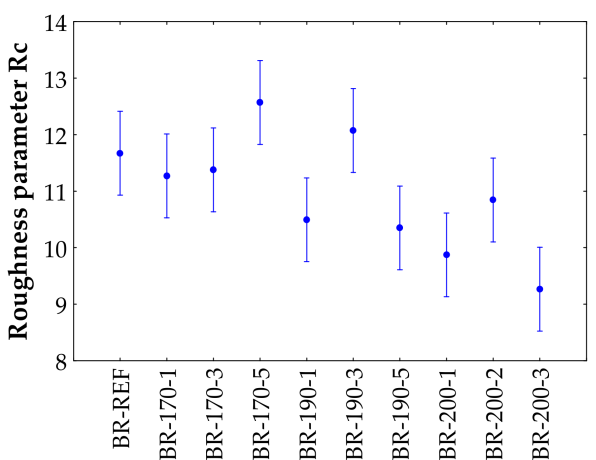

(b)

Figure 6. The graphic visualization of the effect of heat-treatment temperature and heat-treatment time limit (peak stage) on roughness parameters determined by contact method (a) Ra, (b) RSm and (c) Rc. BR-REF = untreated birch; BR-170-1 = birch treated at $170{ }^{\circ} \mathrm{C} / 1 \mathrm{~h}$; BR-170-3 = birch treated at $170{ }^{\circ} \mathrm{C} / 3 \mathrm{~h}$; BR-170-5 = birch treated at $170{ }^{\circ} \mathrm{C} / 5 \mathrm{~h}$; BR-190-1 = birch treated at $190^{\circ} \mathrm{C} / 1 \mathrm{~h}$; BR-190-3 = birch treated at $190{ }^{\circ} \mathrm{C} / 3 \mathrm{~h}$; BR-190-5 = birch treated at $190^{\circ} \mathrm{C} / 5 \mathrm{~h}$; BR-200-1 = birch treated at $200{ }^{\circ} \mathrm{C} / 1 \mathrm{~h}$; BR-200-2 $=$ birch treated at $200{ }^{\circ} \mathrm{C} / 2 \mathrm{~h} ; \mathrm{BR}-200-3=$ birch treated at $200{ }^{\circ} \mathrm{C} / 3 \mathrm{~h}$. Ra $=$ the average arithmetical deviation of the profile; $\mathrm{RSm}=$ the average width of the profile elements; $\mathrm{Rc}=$ the average height of the profile.

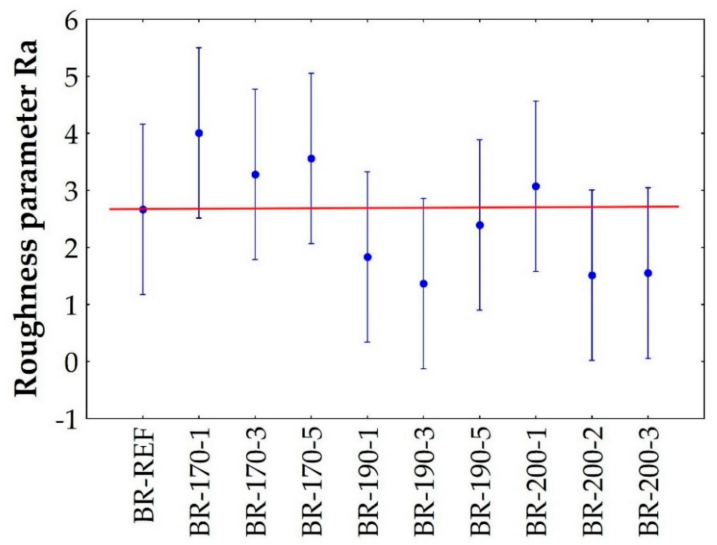

Figure 7. The graphic visualization of the effect of heat-treatment temperature and heat-treatment time limit (peak stage) on roughness parameter Ra determined by optical method with label of values from the untreated birch (red line). BR-REF = untreated birch; BR-170- $1=$ birch treated at $170{ }^{\circ} \mathrm{C} / 1 \mathrm{~h}$; BR-170-3 = birch treated at $170{ }^{\circ} \mathrm{C} / 3 \mathrm{~h}$; BR-170-5 = birch treated at $170{ }^{\circ} \mathrm{C} / 5 \mathrm{~h}$; BR-190-1 = birch treated at $190{ }^{\circ} \mathrm{C} / 1 \mathrm{~h}$; BR-190-3 = birch treated at $190{ }^{\circ} \mathrm{C} / 3 \mathrm{~h}$; BR-190-5 = birch treated at $190{ }^{\circ} \mathrm{C} / 5 \mathrm{~h}$; BR-200-1 = birch treated at $200{ }^{\circ} \mathrm{C} / 1 \mathrm{~h}$; BR-200-2 = birch treated at $200{ }^{\circ} \mathrm{C} / 2 \mathrm{~h}$; BR-200-3 = birch treated at $200{ }^{\circ} \mathrm{C} / 3 \mathrm{~h}$. 


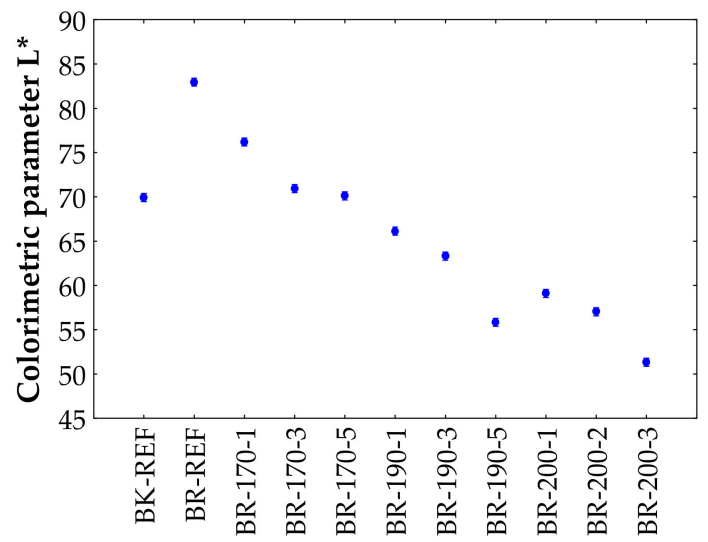

(a)

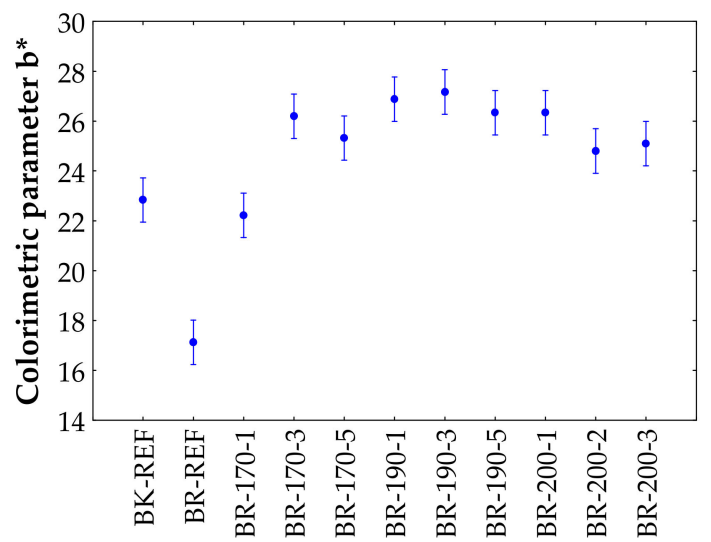

(c)

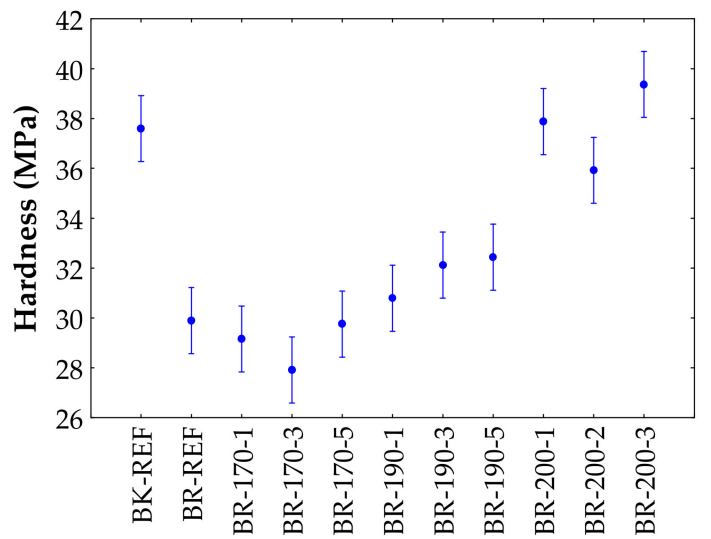

(e)

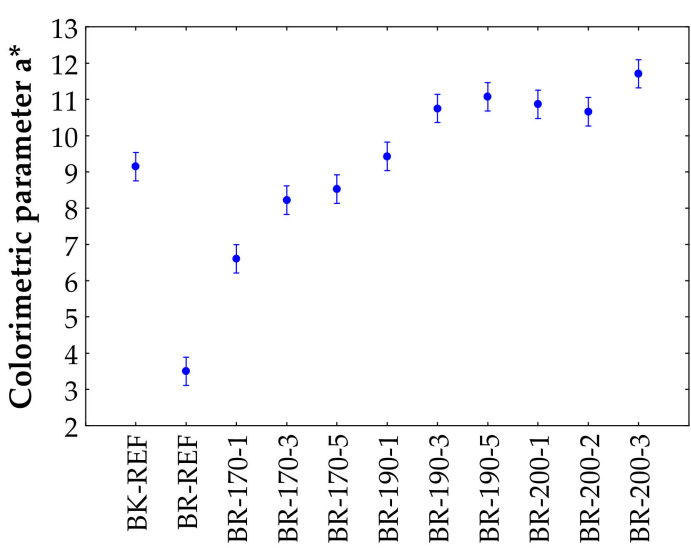

(b)

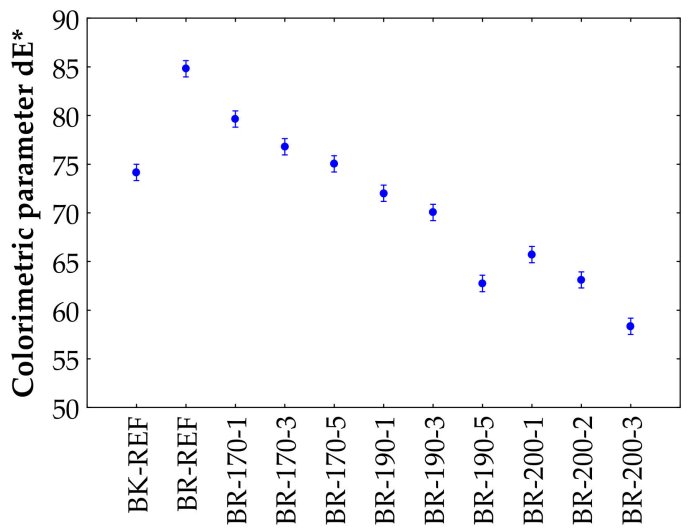

(d)

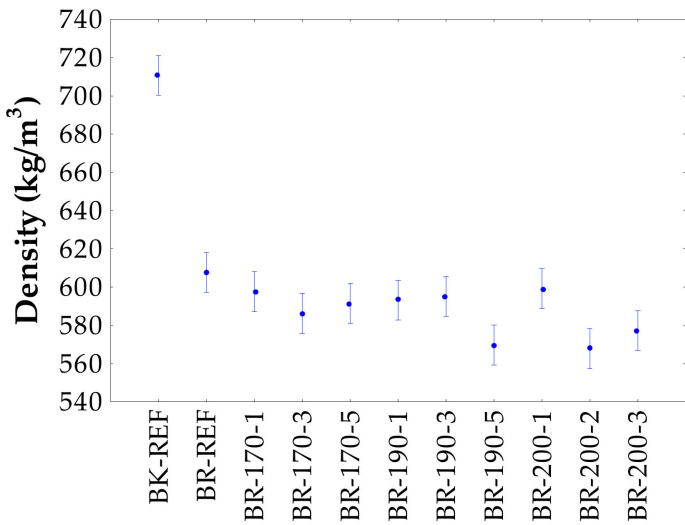

(f)

Figure 8. The graphic visualization of the effect of heat-treatment temperature and heat-treatment time limit (peak stage) on colorimetric parameters (a) $\mathrm{L}^{*},(\mathbf{b}) \mathrm{a}^{*},(\mathbf{c}) \mathrm{b}^{*},(\mathbf{d}) \mathrm{dE}^{*},(\mathbf{e})$ hardness and (f) density. BK-REF = untreated beech; BR-REF = untreated birch; BR-170-1 = birch treated at $170{ }^{\circ} \mathrm{C} / 1 \mathrm{~h}$; BR-170-3 = birch treated at $170{ }^{\circ} \mathrm{C} / 3 \mathrm{~h}$; BR-170-5 = birch treated at $170{ }^{\circ} \mathrm{C} / 5 \mathrm{~h}$; BR-190-1 = birch treated at $190{ }^{\circ} \mathrm{C} / 1 \mathrm{~h}$; BR-190-3 = birch treated at $190^{\circ} \mathrm{C} / 3 \mathrm{~h}$; BR-190-5 = birch treated at $190{ }^{\circ} \mathrm{C} / 5 \mathrm{~h}$; BR-200-1 = birch treated at $200{ }^{\circ} \mathrm{C} / 1 \mathrm{~h} ; \mathrm{BR}-200-2=$ birch treated at $200{ }^{\circ} \mathrm{C} / 2 \mathrm{~h} ; \mathrm{BR}-200-3=$ birch treated at $200{ }^{\circ} \mathrm{C} / 3$ h. $L^{*}=$ brightness; $a^{*}=$ value in the green-red axis; $b^{*}=$ value in the blue-yellow axis; $d E^{*}=$ total color difference. 


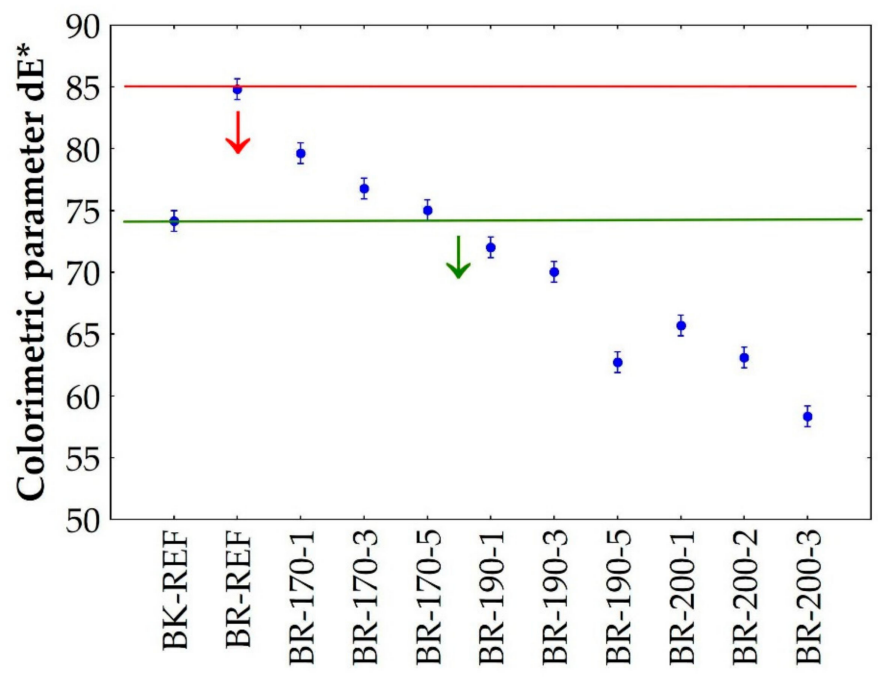

Figure 9. The graphic visualization of the effect of heat-treatment temperature and heat-treatment time limit (peak stage) on colorimetric parameter $\mathrm{dE}^{*}$ (total color difference) with label the necessary shift of values from the untreated birch (red line) below the values of the untreated beech (green line). BK-REF $=$ untreated beech; BR-REF = untreated birch; BR-170- $1=$ birch treated at $170{ }^{\circ} \mathrm{C} / 1 \mathrm{~h}$; BR-170-3 = birch treated at $170{ }^{\circ} \mathrm{C} / 3 \mathrm{~h}$; BR-170-5 = birch treated at $170{ }^{\circ} \mathrm{C} / 5 \mathrm{~h}$; BR-190-1 = birch treated at $190{ }^{\circ} \mathrm{C} / 1 \mathrm{~h}$; BR-190-3 = birch treated at $190^{\circ} \mathrm{C} / 3 \mathrm{~h}$; BR-190-5 = birch treated at $190^{\circ} \mathrm{C} / 5 \mathrm{~h}$; BR-200-1 = birch treated at $200{ }^{\circ} \mathrm{C} / 1 \mathrm{~h} ; \mathrm{BR}-200-2$ = birch treated at $200{ }^{\circ} \mathrm{C} / 2 \mathrm{~h} ; \mathrm{BR}-200-3=$ birch treated at $200{ }^{\circ} \mathrm{C} / 3 \mathrm{~h}$.

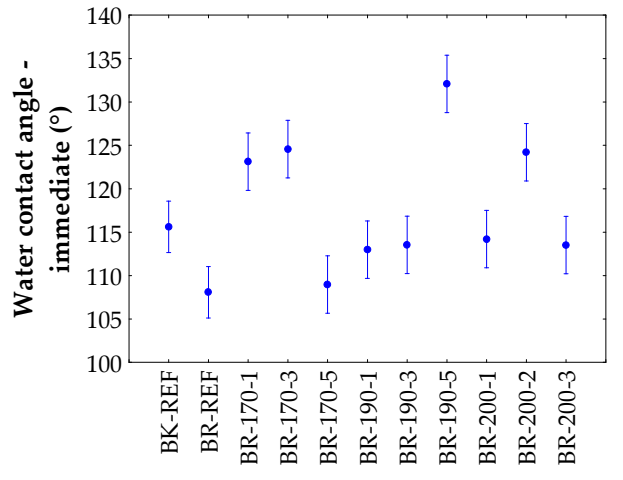

(a)

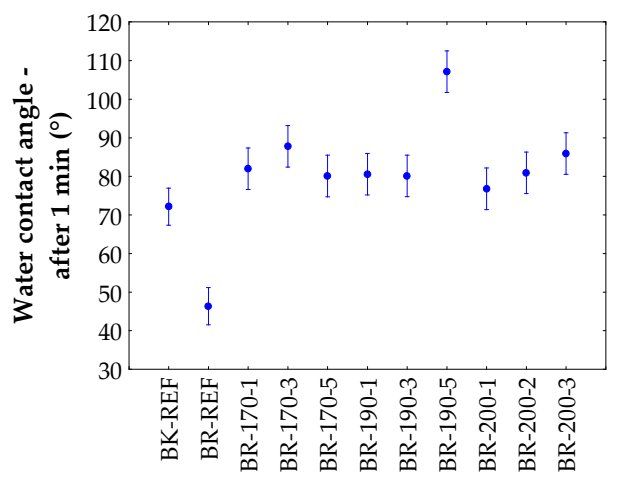

(c)

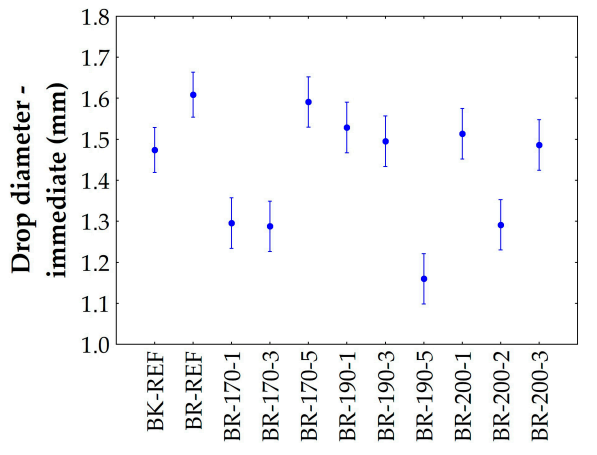

(b)

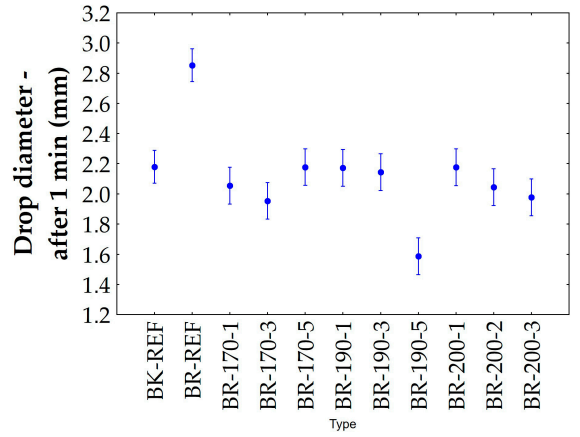

(d)

Figure 10. Cont. 


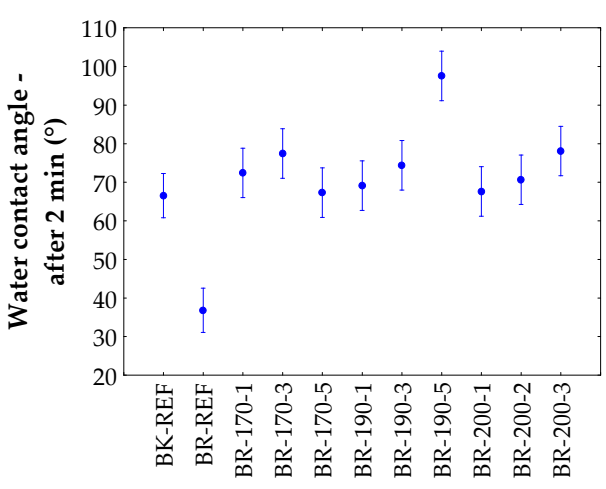

(e)

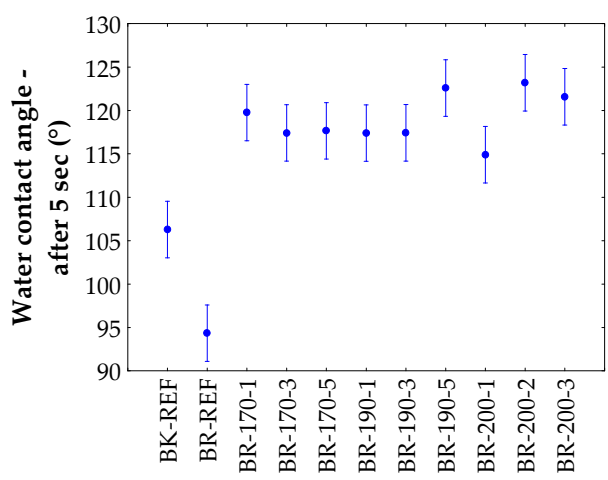

(g)

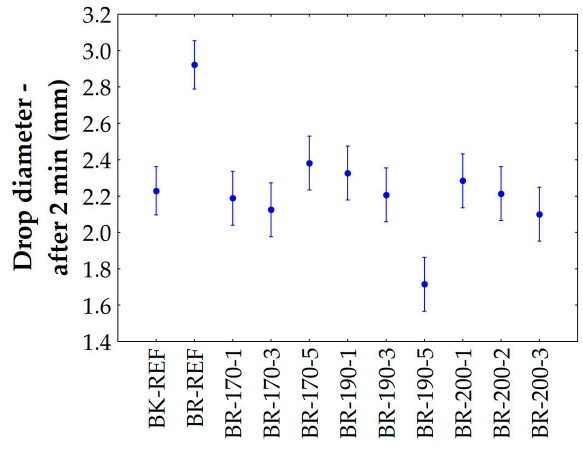

$(\mathbf{f})$

Figure 10. The graphic visualization of the effect of heat-treatment temperature and heat-treatment time limit (peak stage) on wetting parameters (a) water contact angle-immediate, (b) drop diameter-immediate, (c) water contact angle-after $1 \mathrm{~min}$, (d) drop diameter-after $1 \mathrm{~min}$, (e) water contact angle-after $2 \mathrm{~min}$, (f) drop diameter-after $2 \mathrm{~min}$ and (g) water contact angle-after $5 \mathrm{~s}$. $\mathrm{BK}-\mathrm{REF}=$ untreated beech; BR-REF $=$ untreated birch; BR-170-1 = birch treated at $170{ }^{\circ} \mathrm{C} / 1 \mathrm{~h}$; BR-170-3 $=$ birch treated at $170{ }^{\circ} \mathrm{C} / 3 \mathrm{~h} ; \mathrm{BR}-170-5=$ birch treated at $170{ }^{\circ} \mathrm{C} / 5 \mathrm{~h}$; BR-190- $1=$ birch treated at $190{ }^{\circ} \mathrm{C} / 1$ h; BR-190-3 = birch treated at $190{ }^{\circ} \mathrm{C} / 3 \mathrm{~h}$; BR-190-5 = birch treated at $190^{\circ} \mathrm{C} / 5 \mathrm{~h}$; BR-200- $1=$ birch treated at $200{ }^{\circ} \mathrm{C} / 1 \mathrm{~h}$; BR-200-2 = birch treated at $200{ }^{\circ} \mathrm{C} / 2 \mathrm{~h}$; BR-200-3 = birch treated at $200{ }^{\circ} \mathrm{C} / 3 \mathrm{~h}$.

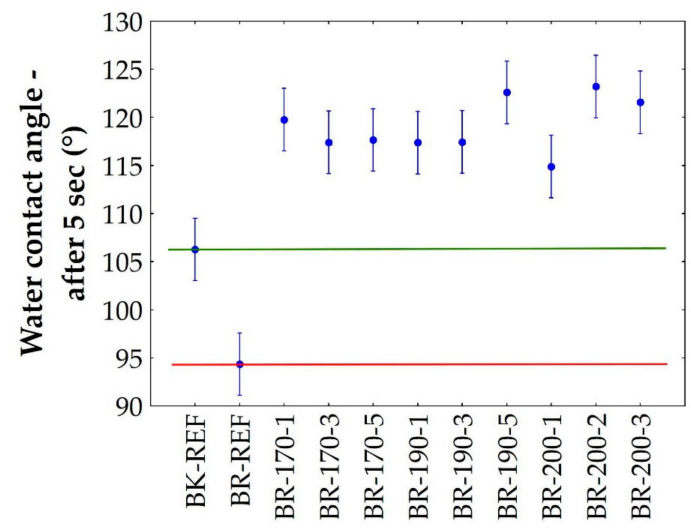

Figure 11. The graphic visualization of the effect of heat-treatment temperature and heat-treatment time limit (peak stage) on wetting parameter (water contact angle-after $5 \mathrm{~s}$ ) with label of values from the untreated birch (red line) and untreated beech (green line). BR-REF $=$ untreated birch; BR-170-1 = birch treated at $170{ }^{\circ} \mathrm{C} / 1 \mathrm{~h}$; BR-170-3 = birch treated at $170{ }^{\circ} \mathrm{C} / 3 \mathrm{~h} ; \mathrm{BR}-170-5=$ birch treated at $170{ }^{\circ} \mathrm{C} / 5 \mathrm{~h}$; BR-190-1 = birch treated at $190^{\circ} \mathrm{C} / 1 \mathrm{~h}$; BR-190-3 = birch treated at $190^{\circ} \mathrm{C} / 3 \mathrm{~h}$; BR-190-5 = birch treated at $190{ }^{\circ} \mathrm{C} / 5 \mathrm{~h}$; BR-200-1 = birch treated at $200{ }^{\circ} \mathrm{C} / 1 \mathrm{~h}$; BR-200-2 = birch treated at $200{ }^{\circ} \mathrm{C} / 2 \mathrm{~h}$; BR-200-3 = birch treated at $200^{\circ} \mathrm{C} / 3 \mathrm{~h}$. 
In the case of the hardness results, it should be noted that beech and birch veneers were used with boundary spans with regards to the density (see Figure $8 \mathrm{e}, \mathrm{f}$ ). The density of the untreated birch veneer was about $608 \mathrm{~kg} / \mathrm{m}^{3}$ and the beech veneer was about $711 \mathrm{~kg} / \mathrm{m}^{3}$, which is a difference of about $15 \%$. Although the density decreases due to the heat treatment, at the temperature of $200{ }^{\circ} \mathrm{C}$ the birch hardness level approximately reached the hardness level of the beech. Taking the density factor into account, i.e., focusing on the specific strength, the birch was equal to the beech at $190{ }^{\circ} \mathrm{C} / 1 \mathrm{~h}$ (see Figure 12). In any case, it is necessary to realize that the temperature of $200{ }^{\circ} \mathrm{C}$ was already the boundary for the birch wood and by further raising it, it would become too brittle and the hardness would drop sharply. However, there were also trend differences between the hardness of the veneer and the solid wood (see $[1,66]$ ), respective to the trend in the hardness values depending on the temperature and the treatment time.

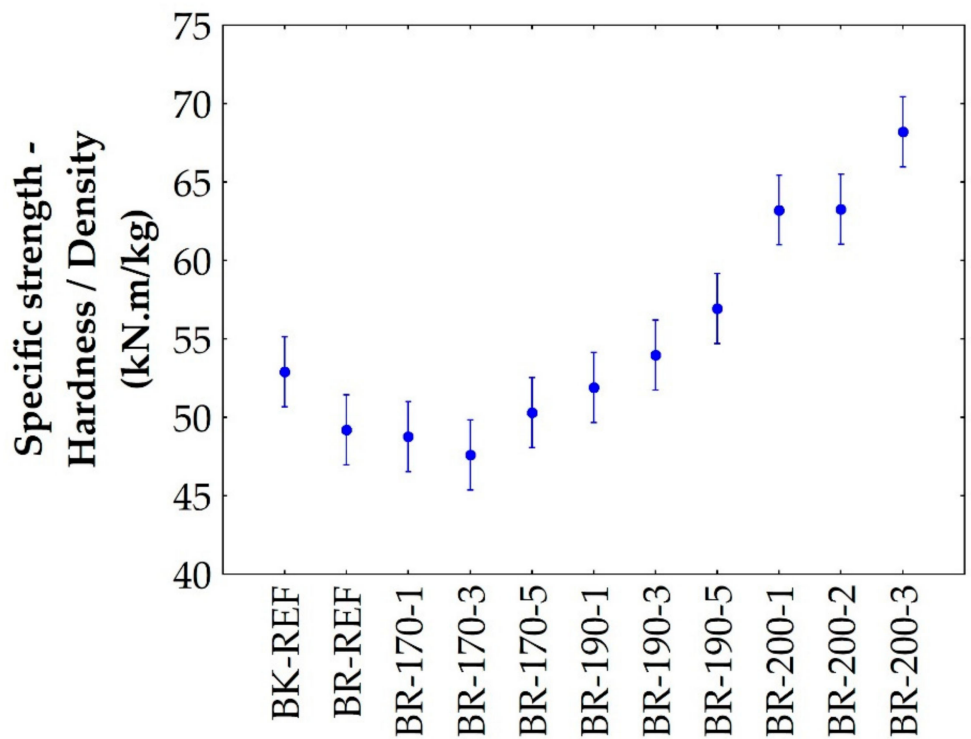

Figure 12. The graphic visualization of the effect of heat-treatment temperature and heat-treatment time limit (peak stage) on specific strength. BK-REF = untreated beech; BR-REF = untreated birch; BR-170-1 = birch treated at $170{ }^{\circ} \mathrm{C} / 1 \mathrm{~h}$; BR-170-3 = birch treated at $170{ }^{\circ} \mathrm{C} / 3 \mathrm{~h}$; BR-170-5 = birch treated at $170{ }^{\circ} \mathrm{C} / 5 \mathrm{~h}$; BR-190- $1=$ birch treated at $190{ }^{\circ} \mathrm{C} / 1 \mathrm{~h}$; BR-190-3 = birch treated at $190{ }^{\circ} \mathrm{C} / 3 \mathrm{~h}$; BR-190-5 = birch treated at $190{ }^{\circ} \mathrm{C} / 5 \mathrm{~h}$; BR-200-1 = birch treated at $200{ }^{\circ} \mathrm{C} / 1 \mathrm{~h}$; BR-200-2 = birch treated at $200{ }^{\circ} \mathrm{C} / 2 \mathrm{~h}$; BR-200-3 = birch treated at $200{ }^{\circ} \mathrm{C} / 3 \mathrm{~h}$.

\subsection{Marketing Evaluation}

Based on the analysis of the results obtained from the questionnaire survey, we can conclude a clear prevailing share in the potential customers who prefer a variant of the heat-treated wood or birch veneer. The share of the respondents willing to buy furniture made of wood or birch veneer with the thermal treatment are shown in Table 5.

Table 5. The proportion of the respondents willing to purchase furniture made of birch wood or veneer with the thermal treatment.

\begin{tabular}{cccc}
\hline Type of Purchase & Sample Group & $\begin{array}{c}\text { Share of the } \\
\text { Respondents }\end{array}$ & $\begin{array}{c}\text { Interval Estimation of } \\
\text { the Share in Population }\end{array}$ \\
\hline Equipment of new & solid wood & 0.912 & $0.857-0.967$ \\
apartment/house & veneer & 0.824 & $0.750-0.898$ \\
\hline Supplementary & solid wood & 0.892 & $0.832-0.952$ \\
accessories & veneer & 0.824 & $0.750-0.898$ \\
\hline
\end{tabular}


The significance level $\alpha=0.05$ was chosen for the calculation of the intervals, i.e., the resulting intervals cover the real proportion of people interested in the furniture with the thermal treatment with a probability of 0.95 . None of the intervals in Table 5 contained the number 0 , so we can reject (at the level of significance 0.05) the hypothesis of zero interest from the people in the Czech Republic in furniture with thermally treated wood. Moreover, none of the intervals contained 0.5 or less, so it can be estimated that the proportion of these people in the population was over half.

\subsubsection{The Preference in the Sample in the Case of Purchasing Accessories and New Furnishings}

Here, we can see the key results of a questionnaire survey answering the question of whether, and to what extent, the individual samples of the solid wood and birch veneer were attractive for the respondents. In the case of the solid wood samples, we can see a greater preference for the darker shades when refurbishing an apartment or a house. People tended to avoid the darkest shade when adding accessories to the existing equipment (see Figure 13). However, these differences were not statistically significant (the significance level achieved is 0.217 ). Furthermore, a low level of preference of solid birch wood samples without heat treatment was apparent, at a level of approximately $9 \%$ in the case of new flat furnishings and approximately $11 \%$ in the case of accessories.

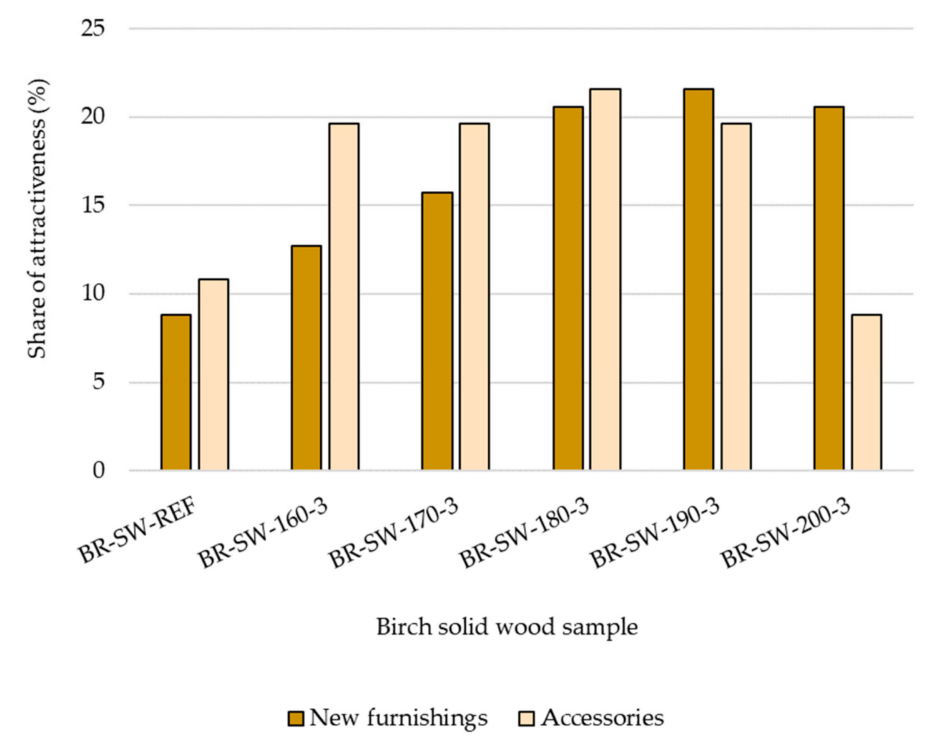

Figure 13. The preference in the samples in the case of purchasing accessories and new furnishing-solid birch wood. BR-SW-REF = untreated birch solid wood; BR-SW-160-3 = birch solid wood treated at $160{ }^{\circ} \mathrm{C} / 3 \mathrm{~h}$; BR-SW-170-3 = birch solid wood treated at $170{ }^{\circ} \mathrm{C} / 3 \mathrm{~h}$; BR-SW-180-3 = birch solid wood treated at $180^{\circ} \mathrm{C} / 3 \mathrm{~h}$; BR-SW-190-3 = birch solid wood treated at $190^{\circ} \mathrm{C} / 3 \mathrm{~h}$; BR-SW-200-3 = birch solid wood treated at $200^{\circ} \mathrm{C} / 3 \mathrm{~h}$.

The tendencies of the birch veneer samples were similar; in the case of new furnishings in a flat or house, medium-dark and darker shades are preferred than the accessories (see Figure 14), but again the differences were not statistically significant (a significance level of 0.601). Furthermore, the low level of preference of birch veneer samples without heat treatment was apparent again, at the level of about $18 \%$ in the case of new flat furnishings and in the case of purchasing accessories. On the other hand, this share was about $100 \%$ higher for new flat furnishings than for the solid wood samples without the heat treatment, where it was only $9 \%$. 


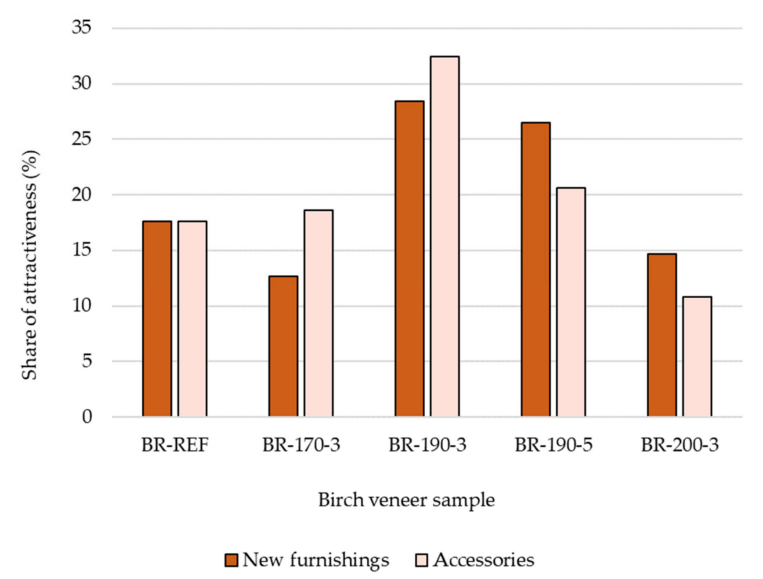

Figure 14. The preference in the samples in the case of purchasing accessories and new flat furnishings-birch veneer. BR-REF = untreated birch veneer; BR-170-3 = birch veneer treated at $170{ }^{\circ} \mathrm{C} / 3 \mathrm{~h}$; BR-190-3 = birch veneer treated at $190{ }^{\circ} \mathrm{C} / 3 \mathrm{~h}$; BR-190-5 = birch veneer treated at $190{ }^{\circ} \mathrm{C} / 5 \mathrm{~h}$; BR-200-3 = birch veneer treated at $200{ }^{\circ} \mathrm{C} / 3 \mathrm{~h}$.

A more detailed look at the structure of the sensitivity level of individual samples is given in Sections 3.2.2 and 3.2.3.

\subsubsection{The Sensitivity of the Measurement of the Attractiveness of the Individual Solid Birch} Wood Samples

The level of attractivity of each individual solid wood sample is shown in Figure 15 and, in detail, in the individual graphs in Figure 16. The maximum number of all the possible responses shown in Figures 15 and 16 is 612 in each figure; 6 responses for one respondent (one response for each solid wood sample) times 102 respondents. Figure 15 shows that, for solid wood, the preference 4 (significant preference-sample liked significantly) was used most often, in 176 response cases. The least used preference was 1 (insignificant preference-the sample liked the least) in 65 cases. The sample BR-SW-180-3 had the highest absolute value of the number of responses in the case of preference 4 , a total of 45 responses. At the same time, the lowest absolute number of responses occurred in this sample, a total of two responses in the case of preference 1. It is also interesting to note that in case of preference 1 , the largest number of responses was found in the reference sample without the heat treatment (BR-SW-REF), which was 26.

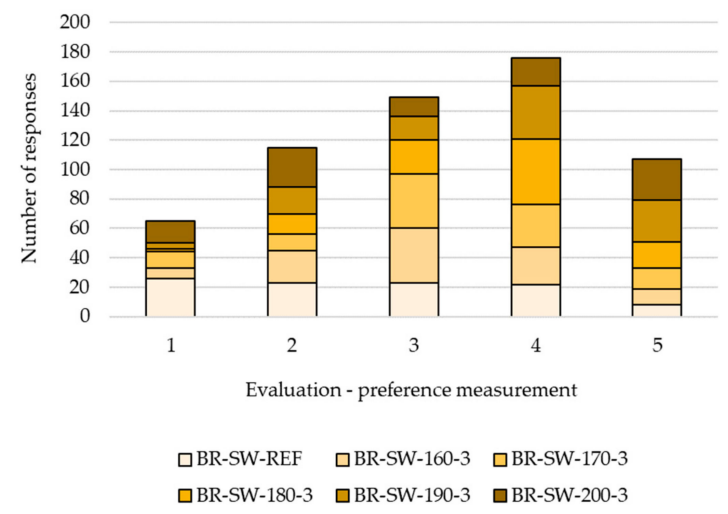

Figure 15. The color distribution of the samples depending on the preference level一solid birch wood. BR-SW-REF = untreated birch solid wood; BR-SW-160-3 = birch solid wood treated at $160{ }^{\circ} \mathrm{C} / 3 \mathrm{~h}$; BR-SW-170-3 = birch solid wood treated at $170{ }^{\circ} \mathrm{C} / 3 \mathrm{~h}$; BR-SW-180-3 = birch solid wood treated at $180^{\circ} \mathrm{C} / 3$ h; BR-SW-190-3 = birch solid wood treated at $190^{\circ} \mathrm{C} / 3 \mathrm{~h}$; BR-SW-200-3 = birch solid wood treated at $200{ }^{\circ} \mathrm{C} / 3 \mathrm{~h}$. 
Figure 16 shows another view of the distribution of the preferences for the solid wood samples. Each individual chart in this figure represents a specific sample of the solid birch wood, and each color in each chart shows the respondents' preference rates for that sample, again from 1 (insignificant preference-the sample liked the least; lightest color in the graphs) to 5 (the most significant preference-the sample liked the most; the darkest color in the graphs). Each graph in the figure represents 102 respondents' answers and the percentage of their preference of 1 to 5 for each sample. The BR-SW-180-3 (62\%) and BR-SW-190-3 (62\%) samples of the respondents obtained a high level of attractiveness (here, we can also include preferences 4 and 5), as well as the BR-SW-200-3 (46\%) and BR-SW-170-3 (42\%). Conversely, BR-SW-REF (47\%), BR-SW-200-3 (41\%) and then BR-SW-160-3 (29\%) obtained low levels of attractiveness (preferences 1 and 2 may be included here).
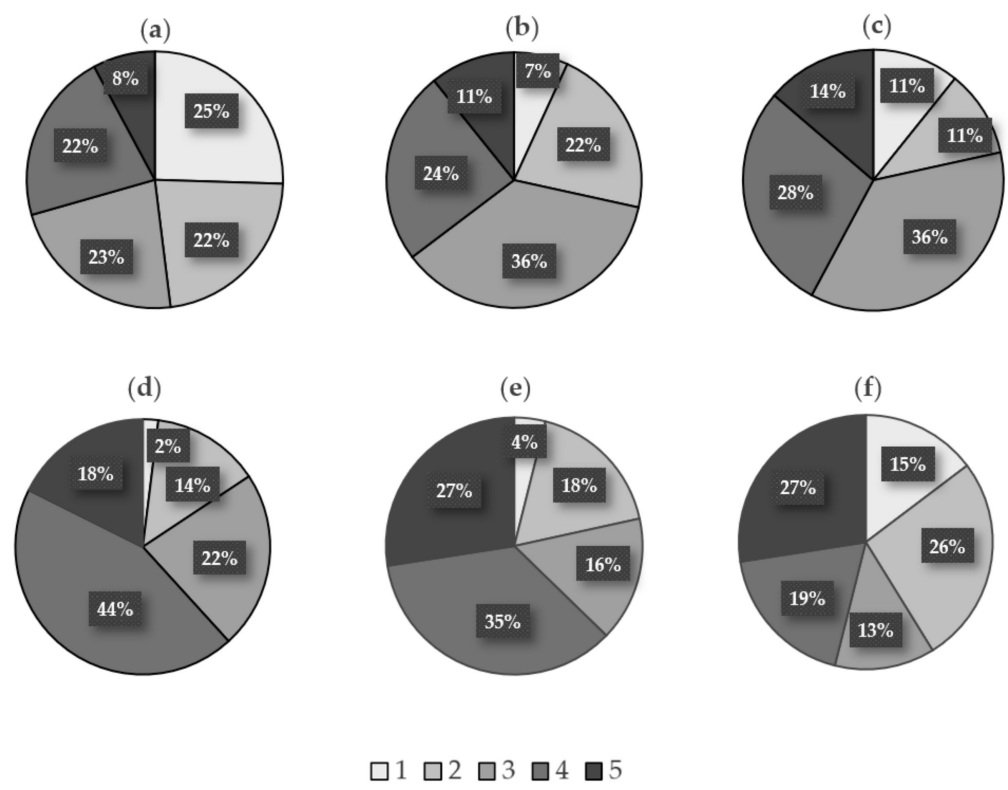

Evaluation - preference measurement

Figure 16. The percentage distribution of the preferences for the individual shades of the samples—solid birch wood. (a) Solid wood-untreated; (b) solid wood—-treated at $160{ }^{\circ} \mathrm{C} / 3 \mathrm{~h}$; (c) solid wood-treated at $170{ }^{\circ} \mathrm{C} / 3 \mathrm{~h}$; (d) solid wood-treated at $180{ }^{\circ} \mathrm{C} / 3 \mathrm{~h}$; (e) solid wood-treated at $190{ }^{\circ} \mathrm{C} / 3 \mathrm{~h}$; (f) solid wood-treated at $200{ }^{\circ} \mathrm{C} / 3 \mathrm{~h}$.

From the graphs in Figures 15 and 16, we can clearly see the prevailing preferences for the heat-treated samples of the solid birch wood, while the preference of the darker shades over the light colors prevailed. An interesting note is that the distribution of preferences for the darkest shade (sample BR-SW-200-3), where there is a significant share in the high preferences (46\% share of preferences 4 and 5) as well as a significant share in the low preferences (41\% share of preferences 1 and 2). It can be seen that, in this sample, the respondents' opinions were divided into two significant groups with conflicting opinions.

\subsubsection{The Sensitivity of the Measurement of the Attractiveness of the Individual Birch Veneer Samples}

The analysis of the results of the sensitivity measure of the attractiveness of individual veneer samples was carried out in principle as in the case of solid wood samples (see Section 3.2.2). The maximum number of all the possible responses shown in Figures 17 and 18 is 510 in each figure, 5 responses of one repondent (one response for each veneer sample) times 102 respondents. The level of attractivity of each individual veneer sample is shown in Figure 17 and, in detail, of the individual graphs in Figure 18. 


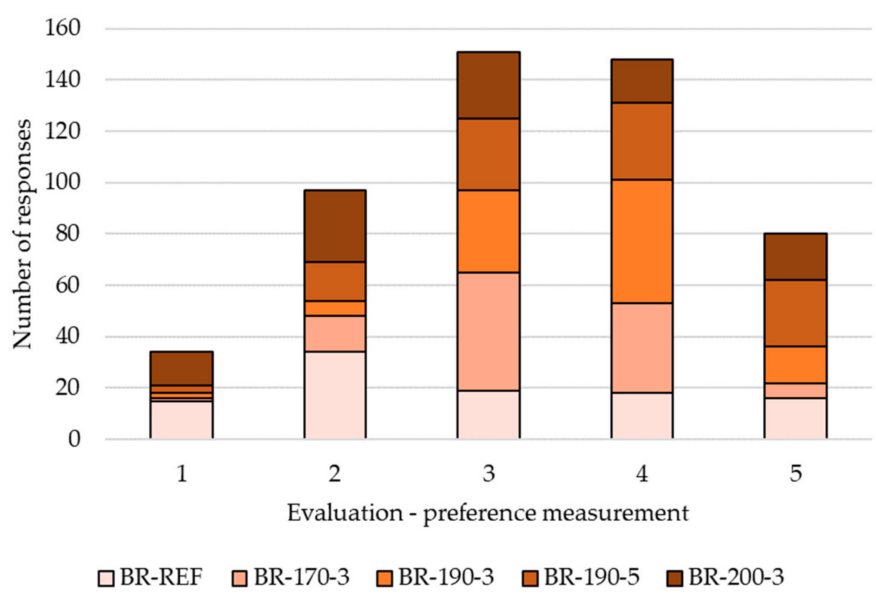

Figure 17. The distribution of the sample colors depending on the preference level-birch veneer. BR-REF = untreated birch veneer; BR-170-3 = birch veneer treated at $170{ }^{\circ} \mathrm{C} / 3 \mathrm{~h}$; BR-190-3 = birch veneer treated at $190{ }^{\circ} \mathrm{C} / 3 \mathrm{~h}$; BR-190-5 = birch veneer treated at $190{ }^{\circ} \mathrm{C} / 5 \mathrm{~h}$; BR-200-3 = birch veneer treated at $200{ }^{\circ} \mathrm{C} / 3 \mathrm{~h}$.
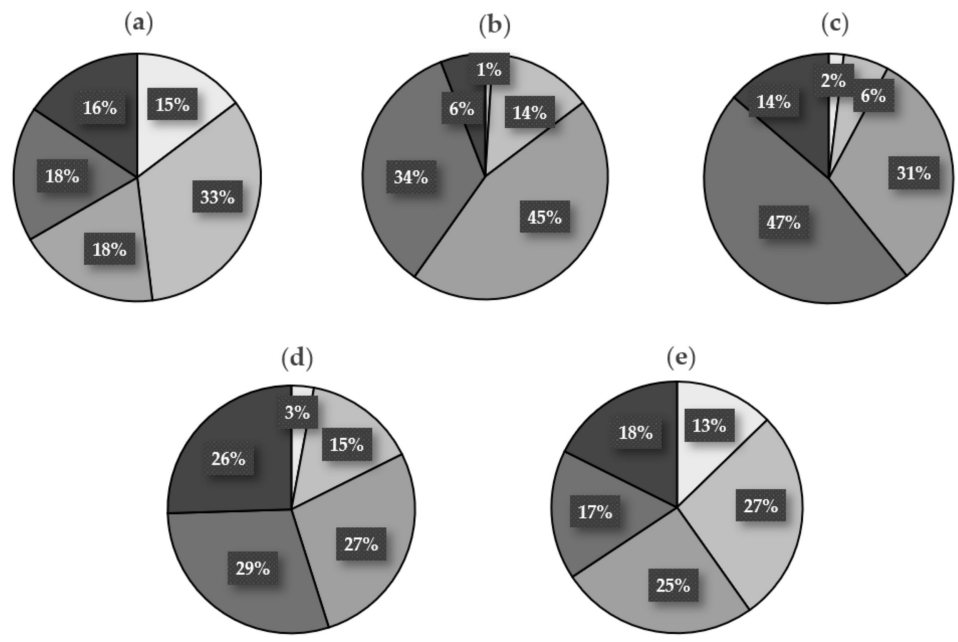

$\square 1 \square 2 \square 3 \square 4 \square 5$

Evaluation - preference measurement

Figure 18. The percentage distribution of the preferences for the individual shades of the samples—birch veneer. (a) Veneer-untreated; (b) veneer-treated at $170{ }^{\circ} \mathrm{C} / 3 \mathrm{~h}$; (c) veneer-treated at $190{ }^{\circ} \mathrm{C} / 3 \mathrm{~h}$; (d) veneer-treated at $190^{\circ} \mathrm{C} / 5 \mathrm{~h}$; (e) veneer-treated at $200{ }^{\circ} \mathrm{C} / 3 \mathrm{~h}$.

Figure 17 shows that for the veneer, preference 3 (medium preference-sample liked on average) was used the most often, in 151 response cases, followed by preference 4 (significant preference-sample liked significantly) in 148 response cases. The least used preference was the same as for the solid wood, preference 1 (insignificant preference-the sample liked the least), in 34 responses. The highest absolute number of responses was BR-190-3 in the case of preference 4, a total of 48 responses, followed by BR-170-3 in the case of preference 3, a total of 46 responses. At the same time, the BR-170-3 sample had the lowest absolute number of responses, a total of one response for preference 1. Curiously, it is also interesting to note that for preference 1 , the highest response rate for the reference sample was untreated (BR-REF), 15, followed by a sample with the highest heat treatment level (BR-200-3), with 13 responses.

Figure 18 shows another view of the preference distribution for the veneer samples. Each individual graph in this figure represents a specific birch veneer sample, and the individual colors in each graph 
show the respondent preference rates for that sample, again from 1 (insignificant preference-the sample liked the least; lightest color in the graphs) to 5 (most significant preference-the sample liked the most; the darkest color in the graphs). Each graph of the figure represents 102 respondents' answers and their percentages of preferences 1 to 5 for each sample. The BR-190-3 (61\%) and BR-190-5 (55\%) samples, as well as the BR-170-3 (40\%) sample, obtained a high level of attractiveness (here we can include preferences 4 and 5). In contrast, BR-REF (48\%) and BR-200-3 (40\%) samples obtained low repetition rates (preferences 1 and 2 here). For other samples, the low level of attractiveness (preference 1 and 2) was less than $20 \%$, while it was the lowest for the BR-190-3 sample (8\%), which, in turn, achieved a high level of attractiveness.

From the graphs in Figures 17 and 18, we can see the prevailing preferences to the heat-treated birch veneer samples in the respondents, with the preference of the medium-dark over the light or darkest shades. An interesting point is in the distribution of the preferences for the lightest shade (reference sample without the BR-REF heat treatment) and the darkest shade (sample BR-SW-200-3), where there is a significant proportion of high preferences (preferences 4 and 5) as well as a significant proportion of low preferences (preferences 1 and 2). It can be seen that, similarly to the darkest solid wood sample, the respondents' opinions were divided into two significant groups with conflicting opinions.

Interviews with individual respondents of the questionnaire survey showed that a lower share of preferences for the heat-treated samples of the peeled veneer compared to the heat-treated samples of the solid wood results from the texture and the arrangement of the early and late wood, where the late wood created a distinctive drawing that was perceived as almost a disturbing one. This implies the importance of guiding the cuts on the samples used, respective to the importance of the method of cutting the material that should be applied to the visible part of the wood product after the heat treatment. This confirms the conclusions of Chen [67], who examined the relationship between the visual images of the wood color and the wood grains of wood products manufactured from the select Taiwanese commercial hardwoods. The author used 23 wood samples, each with tangential and radial sections. The wood color parameters were measured, followed by a survey using the method of semantic differential scaling to determine the consumer's perception of timber products. The different perception of the samples with the tangential and radial sections was proved by the author.

For the visual comparison of the heat-treated peeled veneer samples and the birch sliced veneer samples used, it can be assumed that the heat-treated darker sliced veneer samples could have a higher preference in our questionnaire survey as the late wood texture is not as significant here (see Figure 19). However, a separate investigation would have to be carried out to substantiate the weight of this hypothesis. In the presented research, the samples of the peeled birch veneer were used, because they are expected to have greater potential for use by furniture manufacturers due to their lower cost, resulting, among other things, from lower quality requirements for peeling raw material. For the same reason, the marketing analysis did not consider the samples of beech veneers, where the prices of these veneers in the Czech Republic are higher than in the case of birch. This is due, among other things, to the higher price of beech roundwood assortments of raw wood compared to the same assortment of birch [68].

The analysis of the obtained data from the questionnaire survey unambiguously confirmed the assumptions of other authors [48-52] about the higher attractiveness in the heat-treated wood and veneer compared to the reference samples without the heat treatment. At the same time, the results of the survey indicate a potential change in the sentiment of potential customers in the preference of color shades towards darker colors. However, further investigation would be appropriate to confirm this hypothesis. 


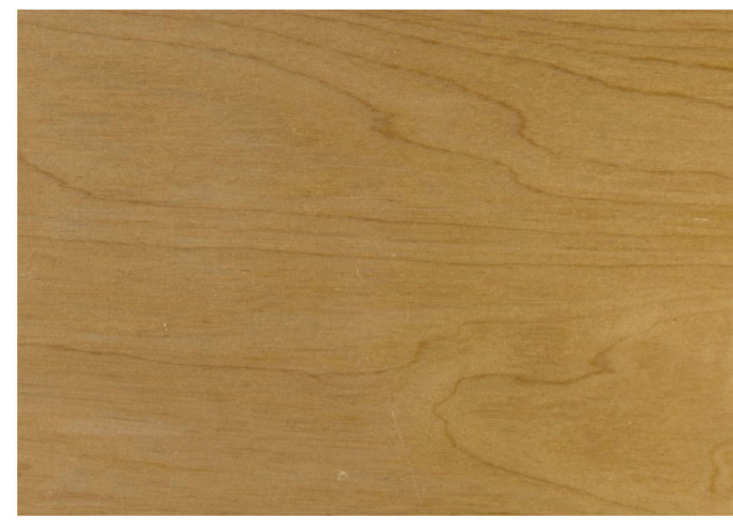

(a)

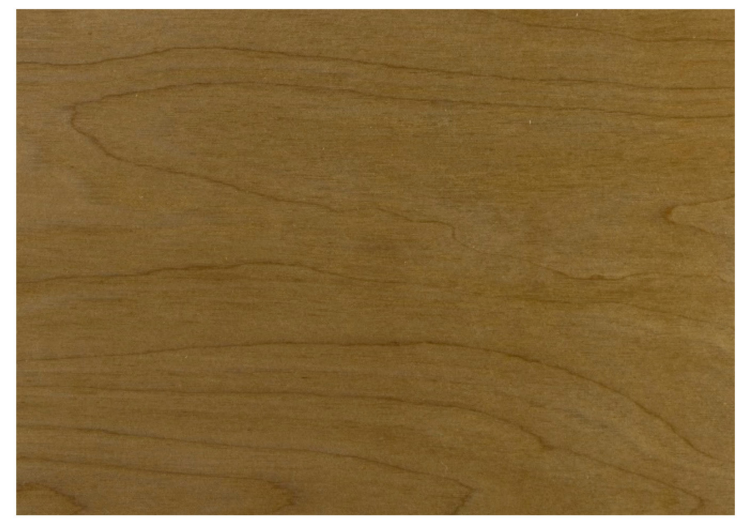

(c)

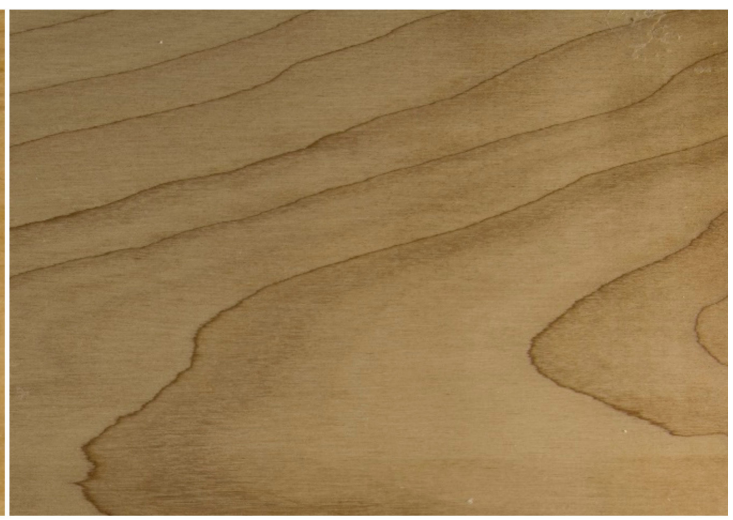

(b)

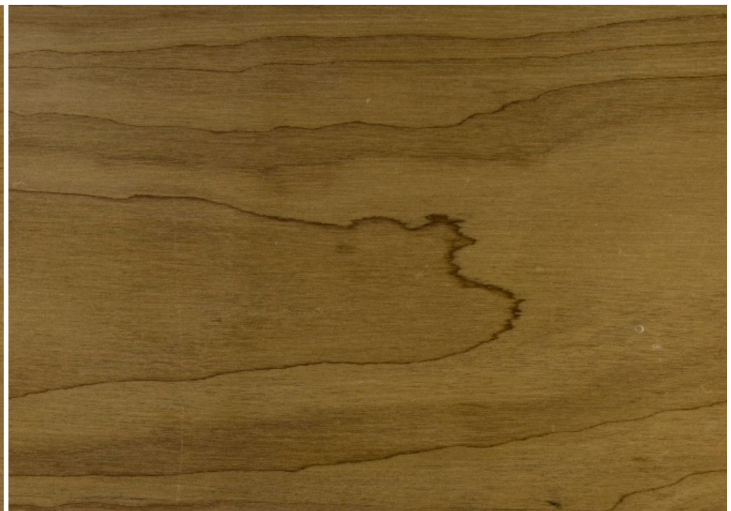

(d)

Figure 19. Photos of the sliced and peeled veneer. Sliced veneer - treated at $190{ }^{\circ} \mathrm{C} / 1 \mathrm{~h}(\mathbf{a})$, peeled veneer-treated at $190{ }^{\circ} \mathrm{C} / 1 \mathrm{~h} \mathrm{(b)}$, sliced veneer-treated at $200{ }^{\circ} \mathrm{C} / 1 \mathrm{~h} \mathrm{(c)}$, peeled veneer -treated at $200{ }^{\circ} \mathrm{C} / 1 \mathrm{~h} \mathrm{(d)}$.

\section{Conclusions}

The surface properties of the birch wood in the form of the veneers, namely the color, hardness, roughness and wetting, did not have any negative changes due to the temperature treatment. A statistically significant effect of the degree of heat treatment was found for all the investigated variables, but not between all the stages.

The color parameters indicate a positive trend in the decrease of the lightness and overall color difference. The wetting parameters, both the contact angle and drop diameter, point to a positive trend in the wettability of the treated birch wood veneers. Although the density decreases due to the heat treatment, at the temperature degree of $200{ }^{\circ} \mathrm{C}$, the hardness of birch wood reached approximately the hardness level of the beech. Taking the density factor into account, i.e., focusing on the specific strength, the birch is equal to the beech at $190{ }^{\circ} \mathrm{C} / 1 \mathrm{~h}$.

The results of the marketing analysis showed, from the customer's point of view, a higher attractiveness in the heat-treated wood and birch veneer compared to reference samples without the heat treatment. A high preference for the medium-dark shades of the heat-treated solid wood and veneer can be observed over the light (including the reference samples without the heat treatment) and the darkest shades. The results also show a greater preference for lighter shades when purchasing apartment/house accessories than for the first furniture of a new apartment/house. However, the differences found here were not statistically significant.

Interviews with the individual respondents of the questionnaire survey provided an interesting finding in the case of the heat-treated samples of the peeled veneer. Here, the respondents perceived the 
distinctive texture of the late wood in the samples with a higher degree of heat treatment, while some respondents either perceived this texture disturbingly or negatively.

The analysis of the respondents' answers and the subsequent interviews with them provided unequivocal support in the intention to continue research in this area. Another topic of research could be the identification of important factors that influence customers' shopping behavior when choosing a product (furniture) from wood or wood-based material. Determining the significance of these factors is also important. On the part of producers, for example, the economic and technical side of the use of material from heat-treated birch wood is important, which also deserves attention.

The results and conclusions presented in this article allow systematically change the view of the possibilities of utilization of birch wood in the conditions of the Czech Republic. It is obvious that a shift of perception of potential use of birch wood from firewood to products with higher value added is possible and correct. This is an important signal for forest owners who can see greater potential in the use of birch in regeneration of large clearings due to salvage fellings in the Czech Republic. From a short-term point of view, the results may play a role in supporting activities leading to grading of quality assortments of birch wood in the current logging of birch stands. These quality assortments can then be used by wood-processing companies, for which these results are also usable.

Author Contributions: Conceptualization, V.B. and R.D.; data curation, V.B. and R.D.; formal analysis, V.B.; funding acquisition, R.D.; investigation, V.B., R.D., A.Z., and T.H.; methodology, V.B. and R.D.; project administration, V.B. and R.D.; resources, V.B., R.D., and A.Z.; software, V.B., R.D. and M.R.; supervision, V.B.; validation, V.B. and R.D.; visualization, V.B. and R.D.; writing—original draft, V.B. and R.D.; writing-review and editing, V.B., R.D., and A.Z. All authors have read and agreed to the published version of the manuscript.

Funding: This research was funded by the EVA 4.0 (grant No. CZ.02.1.01/0.0/0.0/16_019/0000803) financed by OPRDE.

Acknowledgments: We would like to express our thanks to the Faculty of Forestry and Wood Sciences of the Czech University of Life Sciences Prague (for the creating an excellent environment 43300/1322/3240 for manuscript preparation), School Forest Enterprise of the Czech University of Life Sciences in Kostelec nad Černými Lesy, Grant Service of the state enterprise Forests of the Czech Republic and thanks to the manufacturing facility Alfa Plywood in Solnice.

Conflicts of Interest: The authors declare no conflict of interest. 


\section{Appendix A}

Questionnaire

Date:

Write in an answer or select (circle) one of the options:

1. Gender: male - female

2. Age: younger than $15,16-20,21-30,31-40,41-50,51-60,60$ and older

3. Do I have a forestry or timber education (high school and / or university)? yes - no

4. Achieved education: elementary school - secondary school - university

5. If you would completely equip your new house / apartment with furniture (e.g., a living room) from the beginning, what colour would you choose (circle according to the submitted samples - one each from the numbers and letters)

I II III IV V VI

A B C D E

6. If you would like to retrofit / buy some existing furniture (e.g., for a living room), what colour would you choose (circle according to the samples presented - only one sample each from the numbers and letters)

I II III IV V VI

A $B \quad$ C $\quad D \quad E$

7. Evaluate how you like each sample, using a scale of 1 (like the least) to 5 (like the most):

\begin{tabular}{|c|c|c|c|c|c|}
\hline \multirow{3}{*}{$\begin{array}{c}\text { Marking } \\
\text { sample } \\
\text { I: }\end{array}$} & \multicolumn{5}{|c|}{ Preference rate - point scale } \\
\hline & & & & $\rightarrow$ & the most \\
\hline & 1 & 2 & 3 & 4 & 5 \\
\hline II: & 1 & 2 & 3 & 4 & 5 \\
\hline III: & 1 & 2 & 3 & 4 & 5 \\
\hline IV: & 1 & 2 & 3 & 4 & 5 \\
\hline V: & 1 & 2 & 3 & 4 & 5 \\
\hline VI: & 1 & 2 & 3 & 4 & 5 \\
\hline A: & 1 & 2 & 3 & 4 & 5 \\
\hline B: & 1 & 2 & 3 & 4 & 5 \\
\hline C: & 1 & 2 & 3 & 4 & 5 \\
\hline D: & 1 & 2 & 3 & 4 & 5 \\
\hline $\mathrm{E}:$ & 1 & 2 & 3 & 4 & 5 \\
\hline
\end{tabular}

Optional (voluntary) part: If you know, determine / estimate the tree species for each sample:

tree species:

tree species:
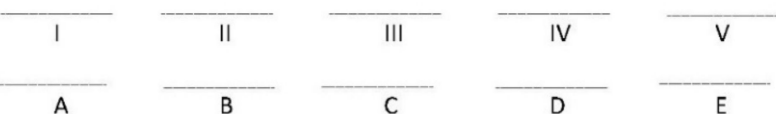

B

D

E

Figure A1. Questionnaire survey form. 


\section{References}

1. Borůvka, V.; Dudík, R.; Zeidler, A.; Holeček, T. Influence of Site Conditions and Quality of Birch Wood on Its Properties and Utilization after Heat Treatment. Part I-Elastic and Strength Properties, Relationship to Water and Dimensional Stability. Forests 2019, 10, 189. [CrossRef]

2. Dudík, R.; Šišák, L.; Riedl, M. Regeneration of declining spruce stands in the Czech Republic economic view of an alternative species composition. In Book of Abstracts Sustainable Forest Management for the Future-the role of managerial economics and accounting, Proceedings of the International Scientific Conference, Zagreb, Croatia, 10-12 May 2018; Posavec, S., Ed.; Faculty of Forestry University of Zagreb: Zagreb, Croatia, 2018; pp. 25-26.

3. Bhuiyan, N. A Framework for successful new product development. J. Ind. Eng. Manag. 2011, 4, 746-770. [CrossRef]

4. Ulrich, K.T.; Eppinger, S.D. Product Design and Development, 4th ed.; McGrawHill: New York, NY, USA, 2007; p. 384.

5. Cooper, R.G. The drivers of success in new-product development. Ind. Mark. Manag. 2019, 76, 36-47. [CrossRef]

6. Arruda, L.M.; Del Menezzi, C.H.S. Effect of thermomechanical treatment on physical properties of wood veneers. Int. Wood Prod. J. 2013, 4, 217-224. [CrossRef]

7. Barnett, J.R.; Jeronimidis, G. Wood Quality and its Biological Basis; Blackwell Publishing: Oxford UK, 2003; p. 226. ISBN 978-1-84127-319-8.

8. Bastani, A.; Adamopoulos, S.; Militz, H. Water uptake and wetting behaviour of furfurylated, N-methylol melamine modified and heat-treated wood. Holz Als Roh-Und Werkst. 2015, 73, 627-634. [CrossRef]

9. Bryne, L.E.; Wålinder, M.E. Ageing of modified wood. Part 1: Wetting properties of acetylated, furfurylated, and thermally modified wood. Holzforsch. 2010, 64, 295-304. [CrossRef]

10. De Oliveira, R.M.; Brisolari, A.; Sales, A.; Gonçalves, D. Wettability, Shrinkage and Color Changes of Araucaria angustifolia After Heating Treatment. Mater. Res. 2010, 13, 351-354. [CrossRef]

11. Fang, C.H.; Mariotti, N.; Cloutier, A.; Koubaa, A.; Blanchet, P. Densification of wood veneers by compression combined with heat and steam. Holz Als Roh-Und Werkst. 2011, 70, 155-163. [CrossRef]

12. Fengel, D.; Wegener, G. Wood: Chemistry, Ultrastructure, Reactions, 2nd ed.; Walter de Gruyter: Berlin, Germany, 1989; p. 613. ISBN 978-0899255934.

13. ITA (International Thermowood Association). Thermowood Handbook; International Thermowood Association: Helsinki, Finland, 2003; Available online: https://asiakas.kotisivukone.com/files/en.thermowood.palvelee.fi/ downloads/tw_handbook_080813.pdf (accessed on 26 November 2019).

14. Liptáková, E.; Kudela, J. Analysis of the Wood-Wetting Process. Holzforschung 1994, 48, 139-144. [CrossRef]

15. Liptáková, E.; Kudela, J.; Bastl, Z.; Spirovová, I. Influence of Mechanical Surface Treatment of Wood on the Wetting Process. Holzforschung 1995, 49, 369-375. [CrossRef]

16. Kocaefe, D.; Poncsak, S.; Doré, G.; Younsi, R. Effect of heat treatment on the wettability of white ash and soft maple by water. Holz Als Roh-Und Werkst. 2008, 66, 355-361. [CrossRef]

17. Korkut, S.; Budacki, M. The effects of high-temperature heat-treatment on physical properties and surface roughness of rowan (Sorbus Aucuparia, L.) wood. Wood Res. 2010, 55, 67-78.

18. Navi, P.; Girardet, F. Effects of Thermo-Hydro-Mechanical Treatment on the Structure and Properties of Wood. Holzforschung 2000, 54, 287-293. [CrossRef]

19. Navi, P.; Pizzi, A. Property changes in thermo-hydro-mechanical processing. Holzforschung 2015, 69, 863-873. [CrossRef]

20. Navi, P.; Sandberg, D. Thermo-Hydro-Mechanical Wood Processing, 1st ed.; CRC Press: Lausanne, Switzerland, 2012; p. 280. ISBN 978-1439860427.

21. Pánek, M.; Dvořák, O.; Eliška, O.; Šimůnková, K.; Zeidler, A. Effectiveness of Two Different Hydrophobic Topcoats for Increasing of Durability of Exterior Coating Systems on Oak Wood. Coatings 2019, 9, 280. [CrossRef]

22. Petrissans, M.; Gerardin, P.; El Bakali, I.; Serraj, M. Wettability of Heat-Treated Wood. Holzforschung 2003, 57, 301-307. [CrossRef]

23. Reiniati, I.; Osman, N.B.; Mc Donald, A.G.; Laborie, M.-P. Linear viscoelasticity of hot-pressed hybrid poplar relates to densification and to the in situ molecular parameters of cellulose. Ann. For. Sci. 2014, 72, 693-703. [CrossRef] 
24. Reinprecht, L. Wood Deterioration, Protection and Maintenance, 1st ed.; John Wiley \& Sons: Oxford, UK, 2016; p. 376. ISBN 978-1119106531.

25. Sandberg, D.; Haller, P.; Navi, P. Thermo-hydro and thermo-hydro-mechanical wood processing: An opportunity for future environmentally friendly wood products. Wood Mater. Sci. Eng. 2013, 8, 64-88. [CrossRef]

26. Sandberg, D.; Kutnar, A.; Mantanis, G.I. Wood modification technologies-a review. iForest Biogeosci. For. 2017, 10, 895-908. [CrossRef]

27. Shmulsky, R.; Jones, P.D. Forest Products and Wood Science: An Introduction; Wiley: Hoboken, NJ, USA, 2011; p. 496.

28. Tarmian, A.; Mastouri, A. Water-repellent efficiency of thermally modified wood as affected by its permeability. J. For. Res. 2017, 29, 859-867. [CrossRef]

29. Tsoumis, G.T. Science and Technology of Wood-Structure, Properties, Utilization, 1st ed.; Van Nostrand Reinhold: New York, NY, USA, 1991; p. 494. ISBN 9780442239855.

30. Unsal, O.; Candan, Z.; Korkut, S. Wettability and roughness characteristics of modified wood boards using a hot-press. Ind. Crop. Prod. 2011, 34, 1455-1457. [CrossRef]

31. Zobel, B.J.; Buijtenen, J.P. Wood Variation: Its Causes and Control, 1st ed.; Springer: Berlin/Heidelberg, Germany, 1989; p. 363. ISBN 978-3-642-74071-8.

32. Viitaniemi, P.; Ranta-Maunus, A.; Jämsä, S.; Ek, P. Method for Processing of Wood at Elevated Temperatures. Patent EP-0759137 VTT, 11 May 1995.

33. Andersone, I.; Dobele, G.; Andersons, B.; Kurnosova, N.; Kuka, E.; Volperts, A.; Grinins, J. A study of thermo-hydro-treated (THT) birch wood by chemical analysis and Py-GC/MS. Holzforschung 2019, 73, 653-661. [CrossRef]

34. Bekhta, P.; Krystofiak, T.; Proszyk, S.; Lis, B. Evaluation of Dynamic Contact Angle of Loose and Tight Sides of Thermally Compressed Birch Veneer. Drv. Ind. 2018, 69, 387-394. [CrossRef]

35. Bekhta, P.; Proszyk, S.; Krystofiak, T.; Sedliačik, J.; Novak, I.; Mamoňová, M. Effects of short-term thermomechanical densification on the structure and properties of wood veneers. Wood Mater. Sci. Eng. 2015, 12, 40-54. [CrossRef]

36. Bekhta, P.; Proszyk, S.; Krystofiak, T.; Mamoňová, M.; Pinkowski, G.; Lis, B. Effect of thermomechanical densification on surface roughness of wood veneers. Wood Mater. Sci. Eng. 2014, 9, 233-245. [CrossRef]

37. Irbe, I.; Grinins, J.; Andersone, I.; Andersons, B. Susceptibility of thermo-hydro-treated birch plywood to mould and blue stain fungi. Wood Mater. Sci. Eng. 2017, 13, 296-304. [CrossRef]

38. Kúdela, J.; Rešetka, M.; Rademacher, P.; Dejmal, A. Influence of pressing parameters on surface properties of compressed beech wood. Wood Res. 2017, 62, 939-950.

39. Kvietková, M. The Effect of Thermal Treatment of Birch Wood on the Cutting Power of Plain Milling. BioResources 2015, 10, 8528-8538. [CrossRef]

40. Kvietková, M.; Gaff, M.; Gašparík, M.; Kaplan, L.; Barcík, Š. Surface Quality of Milled Birch Wood after Thermal Treatment at Various Temperatures. BioResources 2015, 10, 6512-6521. [CrossRef]

41. Rohumaa, A.; Hunt, C.; Frihart, C.R.; Saranpaa, P.; Ohlmeyer, M.; Hughes, M. The influence of felling season and log-soaking temperature on the wetting and phenol formaldehyde adhesive bonding characteristics of birch veneer. Holzforschung 2014, 68, 965-970. [CrossRef]

42. Sundqvist, B. Color response of Scots pine (Pinus sylvestris), Norway spruce (Picea abies) and birch (Betula pubescens) subjected to heat treatment in capillary phase. Holz Als Roh-Und Werkst. 2002, 60, 106-114. [CrossRef]

43. Bekhta, P.; Sedliačik, J.; Jones, D. Effect of short-term thermomechanical densification of wood veneers on the properties of birch plywood. Holz Als Roh-Und Werkst. 2017, 76, 549-562. [CrossRef]

44. Grinins, J.; Andersons, B.; Irbe, I.; Andersone, I.; Meija-Feldmane, A.; Janberga, A.; Pavlovics, G.; Sansonetti, E. Thermo-hydro treated (THT) birch veneers for producing plywood with improved properties. Holzforschung 2016, 70, 739-746. [CrossRef]

45. Kutnar, A.; Kamke, F.A.; Šernek, M. Density profile and morphology of viscoelastic thermal compressed wood. Wood Sci. Technol. 2008, 43, 57-68. [CrossRef]

46. Kutnar, A.; Kamke, F.A.; Petrič, M.; Šernek, M. The influence of viscoelastic thermal compression on the chemistry and surface energetics of wood. Colloids Surf. A Physicochem. Eng. Asp. 2008, 329, 82-86. [CrossRef] 
47. Dos Santos, D.V.B.; De Moura, L.F.; Brito, J.O. Effect of heat treatment on color, weight loss, specific gravity and equilibrium moisture content of two low market valued tropical woods. Wood Res. 2014, 59, $2-253$.

48. De Cademartori, P.H.G.; Mattos, B.D.; Missio, A.L.; Gatto, D.A. Colour responses of two fast-growing hardwoods to two-step steam-heat treatments. Mater. Res. 2014, 17, 487-493. [CrossRef]

49. Sedlar, T.; Šefc, B.; Stojnić, S.; Jarc, A.; Perić, I.; Sinković, T. Tvrdoća toplinski modificirane bukovine i grabovine. Šumarski List 2019, 143, 433. [CrossRef]

50. Zanuttini, R.; Castro, G.; Cremonini, C.; Negro, F.; Palanti, S. Thermo-vacuum treatment of poplar (Populus spp.) plywood. Holzforschung 2019, 74, 60-67. [CrossRef]

51. Rosu, D.; Teacă, C.-A.; Bodîrlău, R.; Rosu, L. FTIR and color change of the modified wood as a result of artificial light irradiation. J. Photochem. Photobiol. B Biol. 2010, 99, 144-149. [CrossRef]

52. Candelier, K.; Thévenon, M.-F.; Pétrissans, A.; Dumarcay, S.; Gérardin, P.; Petrissans, M. Control of wood thermal treatment and its effects on decay resistance: A review. Ann. For. Sci. 2016, 73, 571-583. [CrossRef]

53. Jirouš-Rajković, V.; Miklečić, J. Heat-Treated Wood as a Substrate for Coatings, Weathering of Heat-Treated Wood, and Coating Performance on Heat-Treated Wood. Adv. Mater. Sci. Eng. 2019, 2019, 1-9. [CrossRef]

54. Loučanová, E.; Paluš, H.; Dzian, M. A Course of Innovations in Wood Processing Industry within the Forestry-Wood Chain in Slovakia: A Q Methodology Study to Identify Future Orientation in the Sector. Forests 2017, 8, 210. [CrossRef]

55. Parobek, J.; Paluš, H. Modelling of wood and wood products flow in the Slovak Republic. In Proceedings of the COST Conference on a European Wood Processing Strategy: Future Resources Matching Products and Innovations, Milan, Italy, 30 May-3 June 2008; Ghent University: Ghent, Belgium, 2008; pp. 93-99.

56. Palátová, P. Value added in sawmilling industry in the Czech Republic. Cent. Eur. For. J. 2019, 65, 60-65. [CrossRef]

57. Oblak, L.; Glavonjić, B.; Barčić, A.P.; Govedič, T.B.; Grošelj, P. Preferences of Different Target Groups of Consumers in Case of Furniture Purchase. Drv. Ind. 2020, 71, 79-87. [CrossRef]

58. Kaputa, V.; Šupín, M. Consumer preferences for furniture. In Wood Processing and Furniture Manufacturing: Present Conditions, Opportunities and New Challenges, Vyhne, Slovakia, 6-8 October 2010; Paluš, H., Ed.; International Association for Economics and Management in Wood Processing and Furniture Manufacturing-WoodEMA, i.a.: Zagreb, Croatia, 2010; pp. 81-90.

59. ČSN EN ISO 11664-4. Kolorimetrie-Část 4: Kolorimetrický Prostor CIE 1976 L $^{*} a^{*} b^{*}$ (Colorimetry-Part 4: CIE $1976 L^{*} a^{*} b^{*}$ Colour Space); Czech Office for Standards, Metrology and Testing: Prague, Czech Republic, 1 November 2011.

60. ČSN EN ISO 11664-6. Kolorimetrie-Část 6: CIEDE2000 Vzorce Výpočtu Barevného Rozdílu (Colorimetry-Part 6: CIEDE2000 Colour-Difference Formula); Czech Office for Standards, Metrology and Testing: Prague, Czech Republic, 1 March 2017.

61. ČSN EN ISO 4287. Geometrické Požadavky na Výrobky (GPS)-Struktura Povrchu: Profilová Metoda-Termíny, Definice a Parametry Struktury Povrchu (Geometrical Product Specifications (GPS)-Surface Texture: Profile Method-Terms, Definitions and Surface Texture Parameters); Czech Standards Institute: Prague, Czech Republic, 1 April 1999.

62. Č́SN EN ISO 4288. Geometrické Požadavky na Výrobky (GPS)-Struktura Povrchu: Profilová Metoda-Pravidla a Postupy Pro Posuzováni Struktury Povrchu (Geometrical Product Specifications (GPS)-Surface Texture: Profile Method-Rules and Procedures for the Assesment of Surface Texture); Czech Standards Institute: Prague, Czech Republic, 1 April 1999.

63. ČSN EN 1534. Dřevěné Podlahoviny-Stanovení Odolnosti Proti Vtisku-Metoda Zkoušení (Wood Flooring-Determination of Resistence to Indentation-Test Method); Czech Office for Standards, Metrology and Testing: Prague, Czech Republic, 1 May 2011.

64. ČSN 49 0108. Drevo. Zist'ovanie Hustoty (Wood. Determination of the Density); Czech Standards Institute: Prague, Czech Republic, 1 March 1993.

65. Wonnacot, T.H.; Wonnacot, R.J. Introductory Statistics, 3rd ed.; John Wiley: New York, NY, USA, $1977 ;$ p. 650.

66. Borůvka, V.; Zeidler, A.; HoleČek, T.; Dudík, R. Elastic and Strength Properties of Heat-Treated Beech and Birch Wood. Forests 2018, 9, 197. [CrossRef] 
67. Chen, T.-L. A Study of the Visual Physical Characteristics and Psychological Images of Select Taiwanese Hardwoods. For. Prod. J. 2012, 62, 18-24. [CrossRef]

68. Dudík, R.; Palátová, P.; Borůvka, V.; Riedl, M. The prices and utilization of birch and beech raw wood in the Czech Republic-a Bioeconomic Dimension. In Increasing the Use of Wood in the Global Bio-Economy, Proceedings of the Scientific Conference, Belgrade, Serbia, 26-28 September 2018; Glavonjić, B., Ed.; University of Belgrade-Faculty of Forestry: Belgrade, Serbia, 2018; pp. 90-95.

(c)

(C) 2020 by the authors. Licensee MDPI, Basel, Switzerland. This article is an open access article distributed under the terms and conditions of the Creative Commons Attribution (CC BY) license (http://creativecommons.org/licenses/by/4.0/). 